\title{
A Reappraisal of the Inflation-Unemployment Tradeoff
}

\author{
Marika Karanassou, Hector Sala ${ }^{\dagger}$ and Dennis J. Snower ${ }^{\ddagger}$
}

3 November 2003

\begin{abstract}
This paper offers a reappraisal of the inflation-unemployment tradeoff, based on "frictional growth," describing the interplay between nominal frictions and money growth. When the money supply grows in the presence of price inertia (due to staggered wage contracts with time discounting), the price adjustments to each successive change in the money supply are never able to work themselves out fully. In this context, monetary shocks have a gradual and delayed effect on inflation, and these shocks also generate plausible impulse-responses for unemployment. Although our theory contains no money illusion, no permanent nominal rigidities, and no departure from rational expectations, there is a long-run inflation-unemployment tradeoff.
\end{abstract}

Keywords: Inflation, unemployment, Phillips curve, nominal inertia, wageprice staggering, monetary policy, business cycles, forward-looking expectations.

JEL Classifications: E2, E3, E4, E5, J3.

Acknowledgements: We are very grateful to William Baumol, John Flemming, Assar Lindbeck, John Muellbauer, Torsten Persson, Ron Smith, and Mike Woodford for their insightful comments, as well as to seminar participants at Birkbeck College, the European Central Bank, Nuffield College (Oxford), the Institute for International Economic Studies (University of Stockholm), the IZA and University of Bonn, and Warwick University. The paper is part of an IZA funded project on Labor Market Dynamics.

*Department of Economics, Queen Mary, University of London, Mile End Road, London E1 4NS, UK; tel.: $\square 20 \square 7882-5090 ; \square$

$\dagger$ Department $\square$ d'Economia $\square$ Aplicada, $\square$ Universitat $\square$ Autònoma $\square$ de $\square$ Barcelona, $\square$ Edifici $\square$ B-Campus UAB, 08193 Bellaterra, Spain; tel: $\square 935811153 ; \square$

${ }^{\ddagger}$ Department of Economics, Birkbeck College, University $\curvearrowleft f$ London, $\square 7$ Gressel Street, London W1T $\square$ LL, UK; †el: $₫ 020 \square 7631-6408 ; \square$ 


\section{Introduction}

It is well known that the predictions of the New Phillips curve ${ }^{1}$ do not accord with some important empirical regularities, e.g. they have trouble explaining why monetary shocks have delayed and gradual effects on inflation and unemployment and why inflation is so persistent. The traditional Keynesian expectations-augmented Phillips curve does not suffer from these deficiencies, but it has not received proper microfoundations. Since both types of Phillips curves, old and new, are viewed as broadly consistent with a NAIRU or natural rate of unemployment, they share a further major deficiency. It is that if the NAIRU is reasonably stable through time, then inflation must fall (rise) without limit when unemployment is high (low). This predicted "knife-edge behavior" is blatantly counterfactual. These issues are important, since the Phillips curve is central to our understanding of business cycles and widely used in the analysis of monetary policy. ${ }^{2}$

This paper proposes a reappraisal of the inflation-unemployment tradeoff, one that avoids the difficulties above. Our theory is based on a phenomenon we call "frictional growth," growth in the presence of frictions. Specifically, we focus on the interplay between monetary growth and nominal frictions arising from time-contingent staggered nominal contracts. Although our theory contains no money illusion, no permanent nominal rigidities, and no departure from rational expectations, we show that frictional growth implies a downward-sloping relation between inflation and unemployment in the long run. Indeed, for reasonable parameter values, the long-run Phillips curve may be quite flat, and this conclusion is reinforced by simulation results from our empirical model below (Section 7). We also show that the long-run movements of inflation and unemployment are closely related to the shorter run movements. In particular, the slope of the long-run Phillips curve is related to inflation persistence and unemployment persistence in the aftermath of monetary shocks.

In order to analyze the long-run Phillips curve, we need to consider the unemployment rates associated with different long-run inflation rates, and for this purpose we need to analyze

\footnotetext{
${ }^{1}$ It is also known as the "New Keynesian Phillips Curve" or the "New Neoclassical Synthesis." For surveys see, for example, Gali (2002), Goodfriend and King (1997), Mankiw (2001), and Roberts (1995).

${ }^{2}$ See, for example, Clarida, Gali, and Gertler (1999).
} 
the unemployment effects of permanent changes in money growth (corresponding to different long-run inflation rates). These permanent changes may be motivated by changes in a central bank's inflation target or other policy rule. In this respect, our analysis differs from much of the mainstream literature on the New Phillips curve, which tends to focus on persistent after-effects of temporary monetary shocks.

The intuition underlying our derivation of the long-run Phillips curve may be summarized as follows. From the microfoundations of staggered nominal contracts, ${ }^{3}$ it is well known that, when the time discount rate is positive, current nominal values are influenced more strongly by past than by future nominal values. For example, under staggered wage contracts, current wages are a weighted average of past and future prices, with future prices receiving less weight.

When the money supply grows in the presence of this intertemporal weighting asymmetry, the price level chases after a moving "target price." This target price is what the price level would be under instantaneous price adjustment. Since the money supply keeps rising from period to period whereas prices depend more heavily on past prices than future ones, the price adjustments never work themselves out fully. By the time the current price level has begun to respond to the current increase in the money supply, the money supply rises again, prompting a new round of price adjustments.

In this setting, a permanent increase in money growth causes the actual price level to lag further behind the target price. On account of the intertemporal weighting asymmetry, an increase in money growth means that prices fall further behind their target. Whereas the target price remains proportional to the money supply (when there is no money illusion), the actual price level increases less than proportionately to the money supply. Thus, comparing the initial and final steady states, the level of real money balances rises and unemployment falls. By implication the long-run Phillips curve is downward-sloping.

Our analysis indicates that the intertemporal weighting asymmetry plays a dual role. Not only does it give rise to a long-run tradeoff between inflation and unemployment, but it also generates plausible impulse responses to money growth shocks. Unemployment responds quickly,

\footnotetext{
${ }^{3}$ Regarding Taylor contracts, see for example Helpman and Leiderman (1990), Ascari (2000), and Graham and Snower (2002); for Calvo contracts, see for example Bernanke, Gertler and Gilchrist (2000) and Gali (2002).
} 
but the unemployment effect dies down with the passage of time. The inflation response is more delayed and gradual. ${ }^{4}$ In this way, our analysis is in accord with the main stylized facts concerning inflation persistence: gradual reactions of inflation and unemployment to monetary shocks and the absence of knife-edge inflation behavior.

Thus far, downward-sloping long-run Phillips curves have been considered unacceptable on theoretical grounds. In the absence of money illusion - so the conventional argument goes real economic activities do not depend on the unit of account and, by implication, monetary policy can have no long-term effect on unemployment. Our analysis calls this argument into question. The absence of money illusion implies that real economic activities are unaffected by a proportional change in all nominal variables (past, present, and future). But under frictional monetary growth, current nominal variables do not move proportionately to the money supply. As noted, these variables lag behind their target values (which are proportional to the money supply), and the faster the money supply grows (ceteris paribus), the further behind they lag. Thus the absence of money illusion does not imply money super-neutrality. In short, under the standard classical principles, in which all demand and supply functions are homogeneous of degree zero in all nominal variables, it is still possible for monetary shocks to generate a long-run tradeoff between inflation and unemployment.

The paper is organized as follows. In Section 2 we relate our analysis to the existing literature. Section 3 describes our underlying model. Section 4 derives the associated forward-looking short-run Phillips curve, in which current inflation depends on expected future inflation and unemployment. Under rational expectations, expected future inflation depends on agents' information about the current and past macroeconomic variables (and the underlying model). Thus we can derive a closed-form expression of our short-run Phillips curve, in which expected future inflation is expressed in terms of current and past inflation and unemployment. The resulting Phillips curve looks remarkably like the traditional backward-looking Keynesian Phillips curve. It thus turns out that the critical difference between the forward-looking New Phillips curve and the traditional backward-looking one does not hinge - as much of the existing liter-

\footnotetext{
${ }^{4}$ The only non-standard feature is that, in the long run, an increase in money growth leads to a fall in the unemployment rate. However, this feature serves to avoid knife-edge behavior of inflation.
} 
ature suggests - on whether current inflation depends on expected future inflation or on past inflation. ${ }^{5}$

In Section 5 we derive the long-run Phillips curve and explain why it may be reasonably flat in practice. In Section 6 we link the short- and long-run Phillips curves by deriving the impulse-response functions of inflation and unemployment to monetary shocks. We find that the lower is the discount rate, the steeper is the associated long-run Phillips curve (ceteris paribus), but the longer it takes for unemployment and inflation to converge to their longrun values. Empirically, it may be difficult to distinguish between quick convergence to a flat long-run Phillips curve or slow convergence to a steep one (i.e. between permanent versus very prolonged unemployment effects of money growth shocks).

Section 7 provides an illustrative empirical analysis of the U.S. inflation-unemployment tradeoff, allowing for frictional growth. We show that the resulting impulse-response functions are broadly in accord with the stylized facts, and the long-run Phillips curve is far from vertical. Finally, Section 8 concludes with some thoughts on the role of monetary policy in accounting for the path of inflation and unemployment in the U.S. over the 1990s.

\section{Relation to the Literature}

The traditional Keynesian expectations-augmented Phillips curve, in its simplest form, may be expressed as $\pi_{t}=\pi_{t-1}-\gamma\left(u_{t}-u^{n}\right)+\varepsilon_{t}$, where $\pi$ is the inflation rate, $u$ is the unemployment rate, $u^{n}$ is the natural rate of unemployment or NAIRU, $\gamma$ is a positive constant, and $\varepsilon_{t}$ is white noise. It has been called "a fact in search of a theory," since it is in accord with prominent empirical regularities, but has proved difficult to rationalize through microfoundations. The standard textbook version of the New Phillips curve (NPC) is $\pi_{t}=E_{t} \pi_{t+1}-\gamma\left(u_{t}-u^{n}\right)+\varepsilon_{t}{ }^{6}$ where $E_{t}$ denotes expectations set at time $t$. It is far less successful in explaining the stylized facts: inflation persistence, with autocorrelations close to unity $;^{7}$ the delayed, gradual effects

\footnotetext{
${ }^{5}$ We will show, instead, that it hinges on theoretical parameter restrictions which, however, may be inestimable.

${ }^{6}$ Alternatively, the unemployment term may be replaced by another real variable, such as the output gap.

${ }^{7}$ Fuhrer and Moore (1995) argue that although the Taylor model can account for slow adjustment of wages and prices, inflation is a jump variable that can adjust instantly (much like the capital stock adjusts slowly even though investment can adjust instantly).
} 
of monetary shocks on inflation; ${ }^{8}$ hump-shaped unemployment responses to monetary shocks, and the absence of "disinflationary booms" . (So, with some exaggeration, the New Phillips curve might be called "a theory in search of a fact.")

In recent years various attempts have been made to rectify these problems - generally by bringing the predictions of the NPC more closely into line with the traditional one - but no consensus on the nature of the Phillips curve has yet been reached. ${ }^{10}$ As noted, both the New and traditional (expectations-augmented) Phillips curves suffer from the knife-edge problem (viz., if the NAIRU is constant, inflation will change without limit for as long as the unemployment rate differs from this NAIRU. ${ }^{11}$ Empirical support for such behavior is thin to non-existent. There is certainly no evidence of limitlessly large deflation when unemployment is high $\left(u_{t}>u^{n}\right.$ in the traditional Phillips curve) or low $\left(u_{t}<u^{n}\right.$ in the NPC). In Europe, the rise in unemployment over much of the 80's and early 90's despite stable inflation is not in accord with this interpretation. ${ }^{12}$ In the US, the fall in both inflation and unemployment during much of the 90 's does not fit it either.

\footnotetext{
${ }^{8}$ See, for example, Mankiw (2001).

${ }^{9}$ See Ball (1994). When monetary policy is credible, the announcement of a monetary contraction leads firms to expect disinflation, and thus they moderate their price rises even before the money supply slows down. Consequently, real money balances rise, stimulating aggregate demand and reducing unemployment. Conversely, expansionary monetary policy has a contractionary effect on unemployment. In practice the opposite happens; for a recent appraisal, see for example Ball $(1997,1999)$.

${ }^{10}$ The literature is vast; the following are a few examples. Mankiw and Reis (2001) address them in a model where price information disseminates gradually among economic agents. Roberts (1997) constructs a model in which price expectations are not fully rational. Ball (1995) investigates the effects of monetary policy that is not fully credible. Gali (2002) and Gali, Gertler, and Lopez-Salido (2001) examine inflation persistence in terms of price staggering and the cyclical behavior of marginal costs. Lindbeck and Snower (1999) examine the real effects of monetary shocks in the presence of price precommitment and production lags. Huang and Liu (2002) show that wage staggering is more effective than price staggering in amplifying real persistence of monetary shocks. Helpman and Leiderman (1990) and Erceg, Henderson and Levin (2000) examine the interaction between priceand wage-staggering. Some authors, e.g. Estrella and Fuhrer (1998) focus on rigidities such as habit formation in consumption. Other contributors derive real and nominal persistence from complementarities between wageprice staggering and various real rigidities. For instance, Christiano, Eichenbaum, and Evans (2001) and Dotsey, King, and Wolman (1997) examine the interaction between nominal staggering and variable capital utilization. Jeanne (1998) examines the complementarity between price staggering and real wage rigidity. Bergen and Feenstra (2000) investigate the real effects of monetary shocks under staggered price setting in the context of a translog demand structure and roundabout input-output technologies. Kiley (1997) examines the interaction between price staggering and increasing returns in production. Huang and Liu (2001) analyze price staggering in a vertical input-output structure.

${ }^{11}$ Specifically, the traditional Phillips curve implies that $\Delta \pi_{t}=-\gamma\left(u_{t}-u^{n}\right)+\varepsilon_{t}$, so that inflation falls (rises) without limit when unemployment is high (low), relative to the NAIRU. By contrast, the New Phillips curve implies that $\Delta \pi_{t+1}=\gamma\left(u_{t}-u^{n}\right)+\varepsilon_{t+1}$ (where $\varepsilon_{t+1}=\pi_{t+1}-E_{t} \pi_{t+1}$ is an expectational error), so that inflation rises (falls) without limit when past unemployment is high (low).

${ }^{12}$ The rise of European inflation and unemployment in the mid-70s and early $80 \mathrm{~s}$ is not in agreement with the traditional Phillips curve, with a stable NAIRU.
} 
It is worth noting that the strictly microfounded version of the NPC is often expressed as $\pi_{t}=\beta E_{t} \pi_{t+1}-\gamma\left(u_{t}-u^{n}\right)+\varepsilon_{t}$, where $\beta$ is the discount factor. Although this Phillips curve is not subject to the knife-edge problem, the conventional wisdom is that since the discount factor $\beta$ is close to unity, it can usefully be approximated by the textbook version above. On this account, $\beta$ is commonly set equal to unity when the NPC is used for prediction and policy analysis, ${ }^{13}$ and attention in the mainstream literature is focused on explaining inflation persistence rather than avoiding the knife-edge behavior. It is certainly true to say that the conventional analyses of the Phillips curve are broadly compatible with the NAIRU and its knife-edge implications.

There are three ways of dealing with the knife-edge problem. One is to assume that the NAIRU varies through time in agreement with the NAIRU hypothesis. ${ }^{14}$ Then the NAIRU hypothesis becomes tautologous, lacking explanatory power. The charge of tautology can be avoided only if there is convincing ex ante explanatory evidence for the predicted movements of the NAIRU. But such evidence is often hard to come by. For example, if movements in the NAIRU relative to the actual unemployment rate are inversely related to movements in inflation (in accordance with the traditional Phillips curve), then the NAIRU in many continental European countries must have been rising between the mid-70's and early 90's, except for a few years in the late 1980s. But it is far from clear where these NAIRU movements could have come from. The large increases in union density, unemployment benefits and benefit durations, and other welfare state entitlements, the increased stringency of job security legislation, and the big influx of women and young people into the labor force in Europe occurred primarily in the 60's and early 70's. By the 80's and 90's these trends had largely ceased and there were even important moves in the opposite direction. ${ }^{15}$ The alleged fall in the U.S. NAIRU in the

\footnotetext{
${ }^{13}$ See, for example, Gali and Gertler (1999), Romer (1996), Walsh (1998).

${ }^{14}$ In other words, the variations in the NAIRU are such that the resulting difference between the NAIRU and the actual unemployment rate is always inversely proportional to variations in the inflation rate, according to the traditional Phillips curve, or directly proportional to the inflation variations, according to the New Phillips curve.

${ }^{15}$ Rising interest rates and tax rates may well have played a role in driving the NAIRU upwards over the 80 's, but the timing of these factors does not always mesh well with the timing of the unemployment increases in various European countries. The relevant literature is voluminous and well-known; an impressive example is Phelps (1994, ch. 17).
} 
second half of the 90's is also not easy to explain. ${ }^{16}$ With 20-20 hindsight, it is of course possible always to identify new constellations of economic variables that could plausibly have pushed the NAIRU in any direction required by the underlying theory. But the selective nature of this exercise has made a growing number of economists uneasy.

A second way to avoid the knife-edge problem is to suppose that there are long lags in the adjustment of unemployment to macroeconomic shocks, such as the oil price shocks of the mid-70s and early 80s and the interest rate shock of the early 90s. According to this interpretation, the long-run NAIRU in Europe and the U.S. was reasonably stable over the past three decades; the divergent unemployment trajectories in Europe and the U.S. are due to differences in adjustment costs (such as costs of hiring and firing) in the face of some common macroeconomic shocks; and these prolonged unemployment adjustments had little influence on inflation. ${ }^{17}$ This approach also has difficulties: the lagged adjustments need to be very long and variable for the explanation to work, and it is not clear why inflation is not sensitive to the prolonged unemployment adjustments.

A third way of avoiding the knife-edge problem is to dispense with the NAIRU altogether. This approach is pursued here. Our analysis calls into question the conventional view that the long-run Phillips curve is either vertical or nearly vertical and that forward-looking Phillips curves are difficult to reconcile with substantial inflation persistence and unemployment inertia. We show that under plausible empirical assumptions the long-run Phillips curve may be downward-sloping and flat, and that the flatter this slope is, the more under-responsive is inflation to a money growth shock.

Our analysis is in the same spirit as that of Akerlof, Dickens and Perry (1996, 2000), who show that the Phillips curve becomes downward-sloping at low inflation rates when there are permanent downward wage rigidities or departures from rational expectations. But in contrast with these contributions, as noted, our analysis indicates that the long-run Phillips curve is downward-sloping even when there are no permanent nominal rigidities, no money illusion, and no departures from rational expectations.

\footnotetext{
${ }^{16}$ This literature is also well-known. See, for example, Phelps (1999) and Phelps and Zoega(2001).

${ }^{17}$ See, for example, Blanchard and Summers (1986), Lindbeck and Snower (1989, ch. 11), Henry, Karanassou and Snower (2000).
} 
The existing empirical evidence on the NAIRU hypothesis and the slope of the long-run Phillips curve is distinctly mixed, and has led major contributors such as Mankiw (2001) to be "agnostic" on the issue. Given economists' predilection for the classical dichotomy, it is striking that a number of well-known recent studies reject it. King and Watson (1994) and Fair (2000) find a long-run inflation-unemployment tradeoff. Ball (1997) shows that countries experiencing comparatively large and long declines in inflation tend also to encounter comparatively large increases in their NAIRU's. Ball (1999) suggests that such a relationship may be due to monetary policy: countries with relatively contractionary monetary policy in the 1980s tended to have relatively large increases in their NAIRU's. In Bernanke and Mihov (1998) the estimated impulse-response functions of unemployment to monetary shocks do not go to zero (although the estimated influence is statistically insignificant). Akerlof, Dickens and Perry (1996, 2000) find evidence of a long-term tradeoff between inflation and unemployment at low inflation rates. Dolado, Lopez-Salido and Vega (2000) find some evidence of such a tradeoff over the entire range of observations for Spain during 1964-1995.

Our analysis will provide theoretical foundation and empirical support for a long-run inflationunemployment tradeoff. In the process, we will also show that the slope of this tradeoff is closely related to inflation persistence and the impulse responses of inflation and unemployment. We now present a theoretical model which formalizes our central ideas.

\section{The Model}

We construct a maximally simple macro model of frictional growth. For brevity, we skip the standard microfoundations of our macro relations - they are presented in the dynamic general equilibrium model of Graham and Snower (2002) - but we will interpret our results in the light of these microfoundations. All variables in our model - except the unemployment rate - are in logs . All uninteresting constants are ignored.

Aggregate product demand depends on real money balances: ${ }^{18}$

$$
Q_{t}^{D}=M_{t}-P_{t}
$$

\footnotetext{
${ }^{18}$ In the standard derivation of this demand function, households maximize a CES utility function, containing consumption and real money balances as arguments, and additively separable labor.
} 
where $M_{t}$ is the money supply and $P_{t}$ is the price level. The aggregate production function exhibits constant returns to labor: ${ }^{19}$

$$
Q_{t}^{S}=N_{t},
$$

where $N_{t}$ is aggregate employment. The product market clears, so that

$$
Q_{t}^{D}=Q_{t}^{S}
$$

The labor supply is constant:

$$
L_{t}=L,
$$

so that the unemployment rate (not in logs) can be approximated as

$$
u_{t}=L-N_{t} .
$$

Substituting equations (3.1)-(3.4) into (3.5), we obtain a simple unemployment equation:

$$
u_{t}=L-\left(M_{t}-P_{t}\right)
$$

Since the analysis of the long-run Phillips curve naturally requires that we consider the unemployment rates associated with different long-run inflation rates, we need to consider permanent shocks to money growth (corresponding, say, to permanent changes in the central bank's inflation target). For simplicity, let money growth follow a random walk:

$$
\Delta M_{t} \equiv \mu_{t}=\mu_{t-1}+\varepsilon_{t},
$$

where $M_{t}$ is the log of the money supply and $\varepsilon_{t}$ is a white-noise error term. We assume that rational agents at time $t$ know the stochastic process generating money growth, and have information up to the shock $\varepsilon_{t}$, but do not know future realizations of the money growth shock. It is important to note that our qualitative conclusions do not hinge on the random walk assumption. Any money growth process involving a permanent change in money growth (e.g. an $I(0)$ money growth process with a change in money growth regime, or a permanent change in the monetary authority's reaction function) would do. ${ }^{20}$

To close the model, we need to specify the relation between the price level and the money supply. We do this through wage and price setting equations, which depict sluggish nominal

\footnotetext{
${ }^{19}$ Since we seek to derive the long-run inflation-unemployment tradeoff, this labor demand function is interpretted as a long-run relation.

${ }^{20}$ Karanassou, Sala and Snower (2002, Appendix 1) show that although the random walk assumption receives some moderate support from the data, the central results can be derived from other money growth processes as well.
} 
adjustment due to staggered wage contracts à la Taylor $(1979,1980 \mathrm{a}) .{ }^{21}$ We make the standard assumption that there are two nominal wage contracts, each lasting for two periods ${ }^{22}$ and evenly staggered. Let $W_{t}$ be the log of the contract wage, set at the beginning of period $t$ for periods $t$ and $t+1$. The Taylor contract equation is ${ }^{23}$

$$
W_{t}=\alpha W_{t-1}+(1-\alpha) E_{t} W_{t+1}+\gamma\left[c+\alpha \Gamma_{t}+(1-\alpha) E_{t} \Gamma_{t+1}\right]+\omega_{t}
$$

where $\alpha$ and $\gamma$ are positive constants, $0<\alpha<1, E_{t}$ denotes expectations formed in period $t, \omega_{t}$ is a white noise process, and $\Gamma_{t}$ is what Taylor calls "excess demand," i.e. the difference between actual output $\left(Q_{t}\right)$ and full-employment output. Since actual output is $Q_{t}=N_{t}$ and full-employment output is $Q_{t}=L$, in our model,

$$
\Gamma_{t}=Q_{t}-L=-u_{t}
$$

A well-known result from the microfoundations ${ }^{24}$ of the Taylor contract equation is that $\alpha$ is a discounting parameter:

$$
\alpha=\frac{1}{1+\beta}
$$

where $\beta$ is the time discount factor. ${ }^{25}$ The "demand sensitivity parameter" $\gamma$ describes how

\footnotetext{
${ }^{21}$ The main alternative models of time-contingent contracts are (i) the Rotemberg (1982) model (in which each firm is assumed to face quadratic costs of price adjustment, which it minimizes) and (ii) the particularly popular Calvo (1983) model (in which each firm has to keep its price fixed until it receives a random "permissionto-adjust-price" signal, and the probability of receiving this signal remains constant through time). These alternatives however are problematic. In Rotemberg's approach, it is unclear why the cost of price change should be positively related to the magnitude of price change. In fact, the menu cost literature has been built up on the explicit assumption that no such relation exists. Regarding Calvo's approach, it is obviously farfetched to assume that a firm's probability of price adjustment is independent of how long it has been since its last price adjustment. Nevertheless the Calvo model is commonly used as a convenient algebraic shorthand for the Taylor model. However, our analysis, like that of Kiley (2002), calls this presumption into question.

${ }^{22}$ For algebraic simplicity, we assume that the length of the wage contracts is constant through time. Romer (1990) and others provide models of endogenous frequency of nominal adjustment. Our model can be extended in this way, assuming that firms face a tradeoff between the costs of price adjustment and the loss from allowing prices to stray from their frictionless, profit-maximizing levels. However, it is easy to see why this extension makes no substantive difference to our qualitative conclusions: Since greater frequency of adjustment involves higher costs, an increase in money growth does not lead to a completely counterveiling change in contract length, and thus money is not superneutral.

${ }^{23}$ For brevity, once again, we skip the standard derivation of the microfoundations of this contract equation. See Ascari (2000); alternatively, see Huang and Liu (2002) and allow the discount factor to be less than unity.

${ }^{24}$ Helpman and Leiderman (1990), Ascari (2000), and Graham and Snower (2002).

${ }^{25}$ This interpretation of $\alpha$ holds exactly when the steady state money supply is constant. Thus our theoretical
} 
strongly wages are influenced by demand, and the "cost-push parameter" $c$ gives the upward pressure on wages in the absence of excess demand. We assume that the wage setters have knowledge of nominal wages and excess demands up to period $t$, and of the contract shock up to period $t-1$, so that $E_{t} \omega_{t}=0$.

Since there are constant returns to labor in the production function (3.2), the price level is a constant mark-up over the average wage:

$$
P_{t}=\frac{1}{2}\left(W_{t}+W_{t-1}\right)
$$

In sum, our model contains four basic building blocks: (i) the unemployment equation (3.6), (ii) the wage contract equation (3.8), (iii) the price equation (3.11), and (iv) the money supply equation (3.7). The supply and demand sides of the economy are equilibrated through the wage contract equation (3.8): if product supply rises relative to product demand (in period $t$ ), then excess demand $\Gamma_{t}$ falls, putting downward pressure on the nominal wage $W_{t}$. The fall in the nominal wage, in turn, puts downward pressure on the price level (by eq. (3.11)). Thus, given the money supply (3.7), real money balances rise and aggregate demand is stimulated.

In the context of this model, we now proceed to derive the Phillips curve, first in the short-run and then in the long-run.

\section{The Short-Run Phillips Curve}

To derive the short-run Phillips curve, we substitute the wage contract equation (3.8) into the price mark-up equation (3.11) to obtain the following price equation: ${ }^{26}$

$$
\begin{aligned}
P_{t}= & \alpha P_{t-1}+(1-\alpha)\left(E_{t} P_{t+1}+\nu_{t}\right)+\gamma c+\frac{1}{2}\left(\omega_{t}+\omega_{t-1}\right) \\
& +\frac{\gamma}{2}\left(\alpha \Gamma_{t-1}+\alpha \Gamma_{t}+(1-\alpha) E_{t-1} \Gamma_{t}+(1-\alpha) E_{t} \Gamma_{t+1}\right),
\end{aligned}
$$

\footnotetext{
analysis applies to sufficiently small variations in money growth around this steady state. However, our empirical analysis below, as we will see, applies to larger variations, since the estimated behavioral equations are associated with the actual variations in money growth.

${ }^{26}$ To see this, substitute $(3.8)$ into $(3.11)$ and note that $\frac{1}{2}\left(E_{t} W_{t+1}+E_{t-1} W_{t}\right)=\frac{1}{2}\left(E_{t} W_{t+1}+W_{t}\right)+$ $\frac{1}{2}\left(E_{t-1} W_{t}+W_{t-1}\right)-\frac{1}{2}\left(W_{t}+W_{t-1}\right)=E_{t} P_{t+1}+\nu_{t}$
} 
where $\nu_{t}=E_{t-1} P_{t}-P_{t}$ is an expectational error term. Recalling that $\alpha=\frac{1}{1+\beta}$, this equation implies the following forward-looking short-run Phillips curve: ${ }^{27}$

$$
\pi_{t}=\beta E_{t} \pi_{t+1}+(1+\beta) \gamma c-\frac{\gamma}{2}\left[u_{t-1}+(1+\beta) E_{t-1} u_{t}+\beta E_{t} u_{t+1}\right]+\eta_{t},
$$

where $\eta_{t}=\beta \nu_{t}+\frac{(1+\beta)}{2}\left(\omega_{t}+\omega_{t-1}\right)-\frac{\gamma}{2}\left(u_{t}-E_{t-1} u_{t}\right)$ is a random error term. This equation is quite similar to the standard New Phillips curve (given in Section 2), except that inflation depends not just on current unemployment, but also on past and future unemployment. ${ }^{28}$

In the mainstream literature, it is common to derive conclusions about inflation persistence and the effects of monetary policy from such an equation alone. For example, the influential contribution of Fuhrer and Moore (1995) derives the Phillips curve $\pi_{t}=E_{t} \pi_{t+1}+\gamma y_{t}$ and then states "All of the persistence in inflation derives from the persistence in the driving term $y$ (p. 129)" where $y$ is excess demand. This approach is misleading, however, since excess demand $y$ - or unemployment $u$ in our model - is an endogenous variable which, along with inflation $\pi$, is affected by monetary shocks (and other shocks). Thus, inflation persistence in response to monetary shocks can only be examined in the context of a general equilibrium system, containing both the Phillips curve as well as the relation between the real variable (e.g., $y$ or $u$ ) and the monetary shock.

In the context of our analysis, we need to embed the Phillips curve (4.2) in our general equilibrium system above, express the expectations of future inflation in terms of current and past macroeconomic variables, and then derive the impulse response functions of inflation and unemployment to money growth shocks. The first step is to find the equilibrium wage and price level in terms of current and past variables. It can be shown ${ }^{29}$ that the equilibrium nominal wage is

\footnotetext{
${ }^{27}$ Add the term $-(1-\alpha) P_{t}$ to both sides of the previous equation and note that $\Gamma_{t}=Q_{t}-L_{t}=N_{t}-L_{t}=-u_{t}$.

${ }^{28}$ It has been argued (e.g. Roberts (1995)) that since unemployment has a high degree of serial correlation, the weighted average of past, current, and future unemployment may be approximated by the current unemployment rate. But this argument runs afoul of the Lucas critique: the degree to which current unemployment depends on past and future unemployment is affected by macro policy (the monetary policy equation (3.7)) and thus cannot be specified a priori.

${ }^{29}$ The algebraic manipulations underlying these and subsequent steps in this section are given in Karanassou, Sala, and Snower (2002), Appendix 2.
} 


$$
W_{t}=(1-\lambda) c+\lambda W_{t-1}+(1-\lambda) M_{t}+\kappa(1-\lambda) \mu_{t}-(1-\lambda) L+\omega_{t},
$$

where $\lambda=\frac{\frac{\phi_{2}}{\phi_{3}}-\sqrt{\left(\frac{\phi_{2}}{\phi_{3}}\right)^{2}-4\left(\frac{\phi_{1}}{\phi_{3}}\right)}}{2}, \phi_{1}=\alpha\left(1-\frac{\gamma}{2}\right), \phi_{2}=\left(1+\frac{\gamma}{2}\right), \phi_{3}=(1-\alpha)\left(1-\frac{\gamma}{2}\right), \kappa=\frac{\alpha(1+\lambda)}{\frac{\alpha}{1-\alpha}-\lambda}>$ 0 , and $0<\lambda<1$.

The equilibrium price level is

$$
\begin{aligned}
P_{t}= & (1-\lambda) c+\lambda P_{t-1}+(1-\lambda) M_{t}+(1-\lambda)\left(\kappa-\frac{1}{2}\right) \mu_{t} \\
& -\frac{1}{2} \kappa(1-\lambda) \varepsilon_{t}-(1-\lambda) L+\frac{1}{2}\left(\omega_{t}+\omega_{t-1}\right) .
\end{aligned}
$$

Thus the inflation rate is

$$
\pi_{t}=\lambda \pi_{t-1}+(1-\lambda) \mu_{t}+\frac{1}{2}(1-\lambda)(\kappa-1) \varepsilon_{t}+\frac{1}{2} \kappa(1-\lambda) \varepsilon_{t-1}+\frac{1}{2}\left(\omega_{t}-\omega_{t-2}\right) .
$$

Observe that in this equation current inflation $\left(\pi_{t}\right)$ depends on past inflation $\left(\pi_{t-1}\right)$, the money growth rate, and the monetary and real shocks. It is easy to show that the inflation persistence parameter $\lambda$ depends inversely on the discount factor $\beta$ (positively on the discount rate $r$, where $\beta=\frac{1}{1+r}$, the greater the discount rate the greater the persistence parameter $\lambda)$. Thus it is clear that the forward-looking Phillips curve (4.2) is compatible with inflation persistence, given the rest of our general equilibrium system. Note that whereas the persistence parameter $\lambda$ describes the relation between current and past inflation, it does not by itself provide a description of how fast inflation responds to monetary shocks; for the latter purpose, we also need to consider the stochastic structure of the monetary shocks in the inflation equation $(4.5)$.

The price equation (4.4) also implies that equilibrium real money balances are

$$
\begin{aligned}
M_{t}-P_{t}= & -(1-\lambda) c+\lambda\left(M_{t-1}-P_{t-1}\right)+(1-\lambda)\left(\frac{2 \alpha-1}{\gamma}\right) \mu_{t} \\
& +\frac{1}{2} \kappa(1-\lambda) \varepsilon_{t}+(1-\lambda) L-\frac{1}{2}\left(\omega_{t}+\omega_{t-1}\right) .
\end{aligned}
$$

Thus the equilibrium unemployment rate is

$$
u_{t}=(1-\lambda) c+\lambda u_{t-1}-(1-\lambda)\left(\frac{2 \alpha-1}{\gamma}\right) \mu_{t}-\frac{1}{2} \kappa(1-\lambda) \varepsilon_{t}+\frac{1}{2}\left(\omega_{t}+\omega_{t-1}\right) .
$$

The Phillips curve may be defined as an equation that translates an impulse response 
function for inflation (4.5) into an impulse response function for unemployment (4.7), and vice versa. Thus, by equations (4.5), (4.7), and the money supply equation (3.7), we obtain our short-run Phillips curve in closed form:

$$
\pi_{t}=d_{0}+d_{1} \pi_{t-1}-d_{2} u_{t}-d_{3} u_{t-1}+d_{4} u_{t-2}+e_{t}
$$

where

$$
\begin{gathered}
d_{0}=\psi c, d_{1}=\frac{\psi \kappa}{2}, d_{2}=\frac{\psi(1+\kappa)}{2}, d_{3}=\frac{\psi}{2}, d_{4}=\frac{\psi \kappa}{2}, \psi=\frac{1}{\frac{2 \alpha-1}{\gamma}+\frac{\kappa}{2}} \\
e_{t}=\frac{\widetilde{\omega}_{t}}{(1-\lambda B)}, \widetilde{\omega}_{t}=\frac{1}{2}\left[\left(1+\frac{\psi(1+\kappa)}{2}\right) \omega_{t}+\frac{3 \psi}{2} \omega_{t-1}-\left(1+\frac{\psi(\kappa-1)}{2}\right) \omega_{t-2}\right] .
\end{gathered}
$$

The above error term is a moving average process in terms of $\omega_{t}$, with parameters which are non-linear functions of the theoretical parameters $\psi, \kappa$, and $\lambda{ }^{30}$ Inspection of equations (4.9) shows the following relationships among the slope coefficients of (4.8):

$$
d_{1}=d_{4}, \text { and } d_{3}=d_{2}-d_{1}
$$

Note that the closed-form Phillips curve (4.8) looks like the traditional backward-looking Keynesian Phillips curve. Nevertheless, given our macroeconomic model, our closed-form Phillips curve (4.8) is of course equivalent to our forward-looking Phillips curve (4.2). This is noteworthy because the standard way of distinguishing the backward-looking from the forwardlooking Phillips curves is in terms of lags and leads: in the backward-looking curve, current inflation depends on past inflation, whereas in the forward-looking curve it depends on expected future inflation. Our analysis suggests that this distinction is bogus. Since expectations of future inflation can be restated in terms of the current and past values of the variables, any Phillips curve with forward-looking inflation expectations can of course be transformed into a Phillips curve where current inflation depends on past inflation.

What, then, is the relation between the traditional backward-looking, expectations aug-

\footnotetext{
${ }^{30} \psi, \kappa$, and $\lambda$ are of course functions of the more basic time-discount parameter $\alpha$ and the demand-sensitivity parameter $\gamma$. Equation (4.8) can also be expressed as

$$
(1-\lambda B)\left(1-d_{1} B\right) \pi_{t}=d_{0}(1-\lambda)-(1-\lambda B)\left(d_{2}+d_{3} B-d_{4} B^{2}\right) u_{t}+\widetilde{\omega}_{t}
$$
}


mented Keynesian Phillips curve and our forward-looking one? In the traditional Phillips curve, the coefficients on past inflation and on unemployment are unrestricted, with one exception: since the traditional expectations-augmented Phillips curves is compatible with the NAIRU, the coefficient on past inflation was restricted to $d_{1}=1$. In our forward-looking Phillips curve, as we have seen, this restriction does not apply. ${ }^{31}$ Instead, the coefficients of this forward-looking Phillips curve must satisfy the restrictions (4.11) and its error term $\left(\widetilde{\omega}_{t}\right)$ follows the moving average process given by (4.10). ${ }^{32}$

\section{The Long-Run Phillips Curve}

In the long-run steady state, $\pi_{t}=\pi_{t-1}, u_{t}=u_{t-1}$, and the white noises error terms $\varepsilon_{t}$, and $\omega_{t}$ are zero. Thus, by (4.5), the long-run inflation rate is ${ }^{33}$

$$
\pi_{t}^{L R}=\mu_{t}^{L R}
$$

The long-run unemployment rate is (by (4.7))

$$
u_{t}^{L R}=-\frac{(1-\beta)}{\gamma(1+\beta)} \mu_{t}^{L R}+c .
$$

Substituting equation (5.1) into (5.2), we obtain the long-run Phillips curve:

$$
\pi_{t}^{L R}=-\frac{\gamma(1+\beta)}{(1-\beta)} u_{t}^{L R}+\frac{\gamma(1+\beta)}{(1-\beta)} c .
$$

Note that the slope depends on the discount factor $\beta$ and the demand sensitivity parameter $\gamma$.

The intuition underlying this downward-sloping long-run Phillips curve, given in Section 1 , is now easy to confirm. The price level under instantaneous adjustment may be found by letting the time span of each wage contract tend toward zero, so that $\alpha$ tends to $1 / 2$ and $\mu_{t}$

\footnotetext{
${ }^{31}$ In this respect, our forward-looking Phillips curve resembles the old-style Phillips curves prior to the "discovery" of the NAIRU. Our long-run Phillips curve is vertical only when the rate of time discount is zero.

${ }^{32}$ These conditions, however, should not be viewed as restrictions imposed on an estimated Phillips curve equation, for two related reasons. First, the restricted equation may not be estimable. Second, as we argue in Section 7, the phenomenon of frictional growth cannot be captured through single-equation estimation of the inflation-unemployment tradeoff, but requires multi-equation estimation, describing how wages and price depend on the money supply and how unemployment depends on the relation between money and prices (or some other relation between real and nominal variables).

${ }^{33}$ Since money growth follows a random walk, the long run money growth rate varies through time $\left(\mu_{t}^{L R}\right.$ has a time subscript) and the long-run inflation rate is time-varying as well.
} 
to zero. From the real money balance equation (4.6) we find that the resulting "target price level" (frictionless price) is $P_{t}=M_{t}+\theta$, where $\theta$ is a constant: ${ }^{34} \theta=c-L$. However, when the money supply grows in the presence of the intertemporal weighting asymmetry in the wage contract $\left(\alpha>\frac{1}{2}\right)$, then the price level lags behind the moving target price level. Specifically, by (4.6), the steady state price level becomes $P_{t}=M_{t}+\theta-\frac{2 \alpha-1}{\gamma} \mu_{t}$. Clearly, a permanent increase in money growth (a rise in $\mu_{t}$ ) causes the price level to fall below the target price, and consequently real money balances $\left(M_{t}-P_{t}\right)$ rise and unemployment falls.

In the textbook literature on the New Phillips Curve, ${ }^{35}$ the discount factor is set equal to unity $(\beta=1$, so that $\alpha=0.5$ in the contract equation (3.8), i.e. there is no intertemporal weighting asymmetry), thereby making the long-run Phillips curve vertical and consistent with the NAIRU hypothesis. The underlying reasoning - that the discount rate is just a few percent and thus can be approximated by zero - is misleading because (a) the slope of the long-run Phillips curve depends nonlinearly on the discount factor and (b) the effect of the discount factor on the slope depends on the value of the demand sensitivity parameter $\gamma$.

There is little agreement in the literature about the appropriate value of $\gamma$. Taylor (1980b) estimates it to be between 0.05 and 0.1; Sachs (1980) finds it in the range 0.07 and 0.1; Gali and Gertler (1999) estimate it to be between 0.007 and 0.047 ; calibration of microfounded models (e.g. Huang and Liu (2002)) assigns higher values. Table 1 presents the slope of the long-run Phillips curve associated with various values of the discount rate $r$ (where $\beta=\frac{1}{1+r}, \alpha=\frac{1}{1+\beta}$ ) and the $\gamma$ parameter.

\begin{tabular}{|c|c|c|c|c|c|}
\hline \multicolumn{6}{|c|}{ Table 1:Slope of the long-run Phillips curve } \\
\hline \multirow[b]{2}{*}{$r(\%)$} & \multirow[b]{2}{*}{$\beta$} & \multirow[b]{2}{*}{$\alpha$} & \multicolumn{3}{|c|}{ slope } \\
\hline & & & $\gamma=0.05$ & $\gamma=0.07$ & $\gamma=0.10$ \\
\hline 1.0 & 0.990 & 0.502 & -10.1 & -14.1 & -20.1 \\
\hline 2.0 & 0.980 & 0.505 & -5.05 & -7.07 & -10.1 \\
\hline 3.0 & 0.971 & 0.507 & -3.38 & -4.74 & -6.77 \\
\hline 4.0 & 0.962 & 0.510 & -2.55 & -3.57 & -5.10 \\
\hline 5.0 & 0.953 & 0.512 & -2.05 & -2.87 & -4.10 \\
\hline
\end{tabular}

Observe that for discount rates above 2 percent and the above range of $\gamma$ values, the slope

\footnotetext{
${ }^{34}$ We evaluate the target price in the absence of the white noise shocks $\varepsilon_{t}$ and $\omega_{t}$.

${ }^{35}$ See, for example, Blanchard and Fisher (1989, p. 395). The authors however express discomfort with this: "Even under lognormality of money and the price level (actually, even under certainty) the optimal rule is not one in which the parameter is equal to a half" (p. 420).
} 
of the long-run Phillips curve is quite flat. These results, however, are merely suggestive, since the theoretical model above is obviously far too simple to provide a reliable account of the long-run inflation-unemployment tradeoff under frictional growth. For that purpose it would be necessary to examine the role of other growing variables (such as capital and productivity) in conjunction with other frictions (such as unemployment inertia). The illustrative empirical model in Section 7 is a small step in this direction.

It can be shown that, for plausible parameter values, our short-run Phillips curve has a flatter slope and lower intercept than its long-run counterpart. ${ }^{36}$ Figures 1 provide two examples of associated short- and long-run Phillips curves. Observe that although the long-run Phillips curve is nearly vertical when the discount rate (defined annually) is very low (at $0.1 \%$ ) and much flatter when the discount rate is high (5\%), the short-run Phillips curve remains quite flat in both cases.

Figures 1: The Short- and Long-Run Phillips Curves
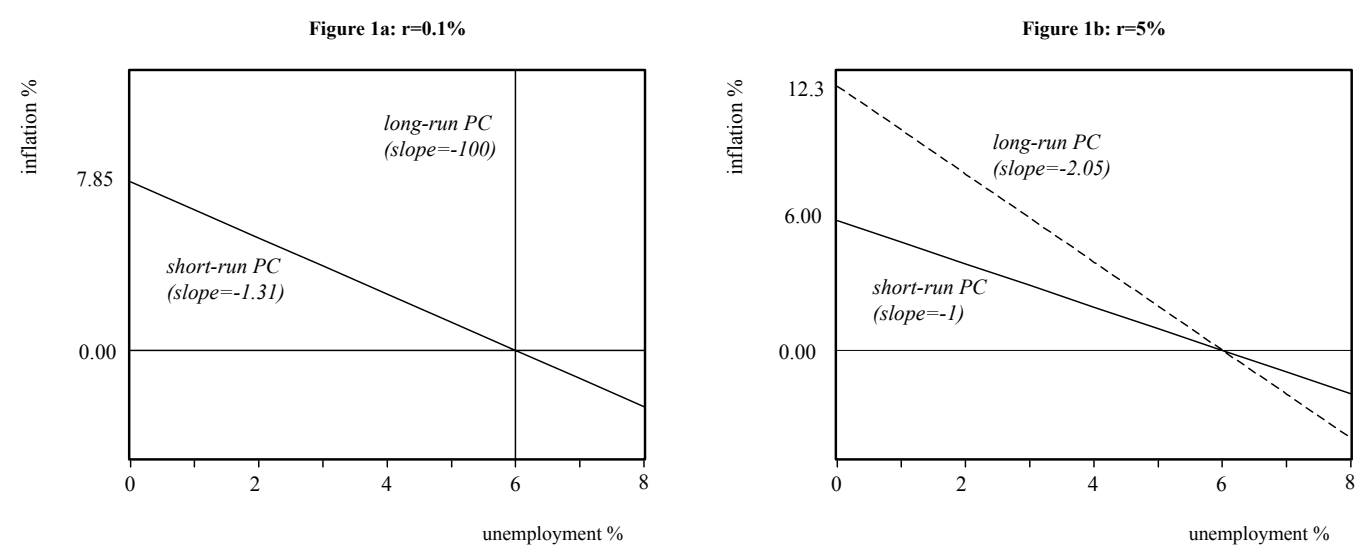

$$
\gamma=0.05, c=0.06
$$

\footnotetext{
${ }^{36}$ In particular, the slope of the short-run Phillips curve (4.8) is $\frac{\partial \pi_{t}}{\partial u_{t}}=d_{2}=-\frac{\gamma+\gamma \kappa}{2(2 \alpha-1)+\gamma \kappa}$ whereas the slope of the long-run Phillips curve (5.3) is $\frac{\partial \pi_{t}^{L R}}{\partial u_{t}^{L R}}=-\frac{\gamma}{2 \alpha-1}$. It can be shown that if, as is plausible, the long-run slope is less than -1 , the long-run Phillips curve is steeper than the short-run one. (This is a sufficient but not necessary condition, as shown in Karanassou, Sala, and Snower (2002), Appendix 2). The intercept of the short-run Phillips curve (4.8) is given by $d_{0}=\left(\frac{2 \gamma}{2(2 \alpha-1)+\gamma \kappa}\right) c$, which is smaller than the long-run Phillips curve (5.3) intercept: $\left(\frac{\gamma}{2 \alpha-1}\right)$ c. (For the underlying derivations, see Karanassou, Sala, and Snower (2002), Appendix 2.)
} 


\section{Theoretical Impulse Response Functions}

We now examine the connection between the short- and long-run Phillips curves by deriving the impulse response functions of inflation and unemployment to a permanent monetary shock, i.e. a one-off unit shock to money growth (3.7), occurring at time $t=0$ : $\varepsilon_{0}=1$ and $\varepsilon_{t}=0$ for $t>0$. At time $t=0$, economic agents know the process (3.7) generating money growth, but not the realizations of the error term $\varepsilon_{t+i}, i \geq 1$.

Thus the monetary shock $\varepsilon_{0}$ is known to the wage setters at time $t=0$, but not at time $t=-1$ (so that the expectations of wage setters at time $t=-1$ are $E_{-1} \varepsilon_{0}=0$ ). Since the current wage $W_{0}$ depends on the past wage $W_{-1}$, the current wage $W_{0}$ does not adjust fully to the shock $\varepsilon_{0}$. On this account, the shock has real effects.

Let $R\left(\pi_{t}\right)$ and $R\left(u_{t}\right)$ be the period- $t$ responses of inflation and unemployment (respectively) to the above money growth shock, ceteris paribus. By the inflation equation (4.5), we find that the inflation responses through time are:

$$
\begin{aligned}
& R\left(\pi_{0}\right)=1+\frac{1}{2}[(1-\lambda) \kappa-(1+\lambda)],
\end{aligned}
$$

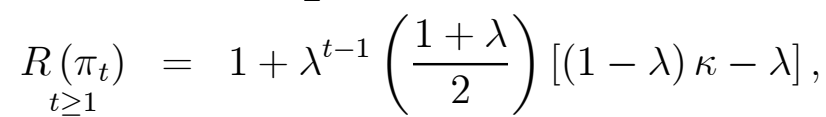

$$
\begin{aligned}
& R\left(\pi_{L R}\right) \equiv \lim _{t \rightarrow \infty} R\left(\pi_{t}\right)=1 \text { (long-run response). }
\end{aligned}
$$

By the unemployment equation (4.7), the unemployment responses through time are:

$$
\begin{gathered}
R\left(u_{t}\right)=-\frac{(1-\beta)}{\gamma(1+\beta)}-\frac{\lambda^{t}(1+\lambda)}{2(1-\lambda)}[(1-\lambda) \kappa-\lambda], \\
R\left(u_{L R}\right) \equiv \lim _{t \rightarrow \infty} R\left(u_{t}\right)=-\frac{(1-\beta)}{\gamma(1+\beta)}, \text { (long-run response). }
\end{gathered}
$$

The impulse-response function for inflation always lies above the initial $(t=0)$ inflation rate, and the impulse-response function for unemployment always lies below the inital $(t=0)$ unemployment rate. It can be shown ${ }^{37}$ that the inflation and unemployment responses fall into two broad classes:

\footnotetext{
${ }^{37}$ See Karanassou, Sala, and Snower (2002), Appendix 2.
} 
1. Inflation and unemployment under-shooting: If $\kappa<\frac{\lambda}{1-\lambda}$, inflation gradually rises toward its new long-run equilibrium $\left(\pi_{t}<\pi_{L R}\right.$, and $\pi_{t+1}>\pi_{t}$ for $\left.t \geq 0\right)$; unemployment gradually falls towards its new long-run equilibrium $\left(\left|u_{t}\right|<\left|u_{L R}\right|\right.$ for $\left.t \geq 0\right)$.

2. Inflation over-shooting slowly and unemployment over-shooting quickly: If $\frac{\lambda}{1-\lambda}<\kappa<$ $\frac{1+\lambda}{1-\lambda},{ }^{38}$ then inflation rises, over-shooting its new long-run equilibrium after one period, and then gradually falls toward this equilibrium $\left(\pi_{0}<\pi_{L R}, \pi_{t}>\pi_{L R}\right.$, and $\pi_{t+1}<\pi_{t}$ for $\left.t \geq 1\right)$. Unemployment falls, over-shooting its new long-run equilibrium, and then gradually rises toward this equilibrium $\left(\left|u_{t}\right|>\left|u_{L R}\right|\right.$, and $\left|u_{t+1}\right|<\left|u_{t}\right|$ for $\left.t \geq 0\right)$. The maximum impact of the monetary shock on unemployment is achieved before the maximum impact on inflation.

For most of the empirically reasonable parameter values given in Table 1, the impulseresponse functions can be shown to fall into Class 2, the class that accords with the stylized facts (viz., the inflation responses to monetary shocks are delayed and gradual, the unemployment responses occur more quickly). Figures 2 depict the impulse response functions for inflation, unemployment, and the slope of the Phillips curve for the same parameter values as in Figures 1. ${ }^{39}$ The horizontal axis measures time; the left-hand vertical axis measures the slope of the Phillips curve; and the right-hand vertical axis measures the inflation and unemployment rates.

Observe when the discount rate is very low $(r=0.1 \%)$, in Fig. 2a, the long-run Phillips curve is virtually vertical, but the short-run Phillips curve at time $t=0$ is very flat, and it takes a very long time for unemployment, inflation, and the Phillips curve slope to reach their long-run values.

By contrast, when the discount rate is higher $(r=5 \%)$, the long-run Phillips curve is quite flat, and it takes a short time for unemployment, inflation, and the slope to reach their long-run values.

\footnotetext{
${ }^{38}$ It can be shown that $\kappa$ cannot exceed $\frac{1+\lambda}{1-\lambda}$.

${ }^{39}$ The value of $c$ has no effect on the slope of the Phillips curve.
} 

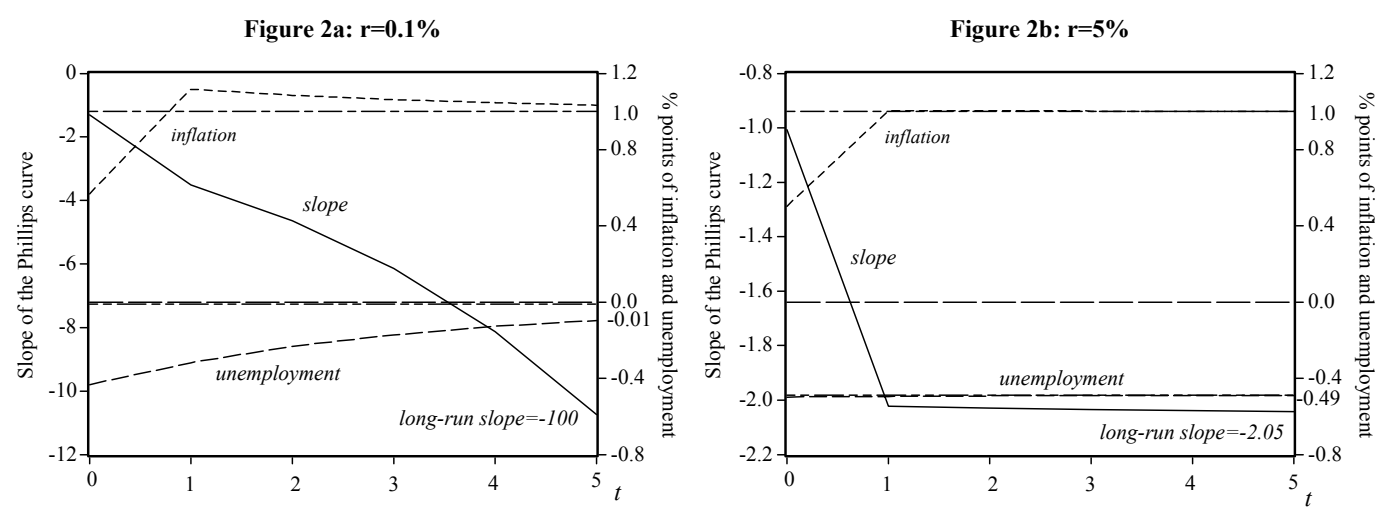

The shock is a $1 \%$ point increase in the money growth rate at $\mathrm{t}=0$

$$
\gamma=0.05
$$

It is easy to show that this pattern holds for the full range of discount rates: The lower the discount rate (for a given value of the demand-sensitivity parameter $\gamma$ ):

- the steeper is the long-run Phillips curve and

- the longer it takes for the slope of the Phillips curve to converge to its long-run value.

Thus, observationally, it may make little difference whether the long-run Phillips curve is flat - so that an increase in money growth permanently reduces unemployment - or near-vertical - so that the effect is not permanent, but very prolonged. In other words, it may be difficult, if not impossible, in practice to distinguish between a world in which there is quick convergence to a flat long-run Phillips curve and one in which there is slow convergence to a steep one. In both cases, money growth shocks have long-lasting effects on unemployment. ${ }^{40}$

\footnotetext{
${ }^{40} \mathrm{In}$ this context it is also easy to show that we can avoid the counterfactual implication of disinflationary booms, analogously to Mankiw and Reis (2001). In the context of the Calvo model of random nominal adjustment, Mankiw and Reis avoid disinflationary booms by assuming that only a fraction of agents receives updated information in each period. The analogue in the Taylor model of fixed, staggered adjustment is to assume that all agents receive information about monetary shocks with a one-period lag. It is trivial to see that if monetary shocks are announced one period in advance and if agents' information about these shocks is received one period in arrears, then the resulting model generates precisely the same results as the model above. More generally, our model avoids the implication of disinflationary booms whenever the lead time for monetary announcements is not greater than the lag time in agents' information updates.
} 


\section{Empirical Analysis}

Our empirical analysis is based on multi-equation estimation, since the phenomenon of frictional growth cannot be captured through the usual procedure of estimating a single-equation Phillips curve. When we estimate a traditional or New Phillips curve as a single equation, we are unable to assess how the effects of money growth work their way through the wage-price adjustment process and thereby affect unemployment. Money growth does not enter a single-equation Phillips curve at all; it is substituted out when the impulse-response function of inflation is substituted into the impulse-response function for unemployment to derive the Phillips curve. On this account, we estimate a dynamic structural model, with the following building blocks, matching those of our theoretical model: a wage setting equation and a price setting equation, to portray nominal sluggishness (so that changes in money growth lead to changes in real money balances), and the unemployment equation indicates how the changes in real money balances affect the unemployment rate.

In most of the current empirical literature, by contrast, the Phillips curve is estimated in a single-equation framework. ${ }^{41}$ It is customary to use the lead of inflation as a proxy for expected future inflation. Thus the NPC can be consistently estimated by generalized method of moments (GMM) or, since the model is linear in the parameters, two stage least squares (TSLS). Bardsen, Jansen and Nymoen (2002), show that the empirical results are sensitive to the choice and exact implementation of the estimation method. Overall, there is no agreement in the recent literature about the appropriate method of estimating the NPC and how to test it against the traditional Phillips curve. Consequently, there is disagreement about whether the empirical evidence favors the traditional or New Phillips curves.

The choice of the forcing variable is crucial when estimating the inflation dynamics associated with the Phillips curve. Gali and Gertler (1999), Gali, Gertler and Lopez (2001) find evidence in support of the NPC only when they use labor income share as the forcing variable. Rudd and Whelan (2001) propose using a present value term of the forcing variable in the

\footnotetext{
${ }^{41}$ The NPC is simply expressed as

$$
\pi_{t}=\beta E_{t} \pi_{t+1}+\gamma x_{t},
$$

where $\beta$ is the discount factor, and the "forcing variable" $x_{t}$ is a measure of excess demand (unemployment rate, output gap) or a measure of real marginal costs (like the wage share).
} 
inflation regression and report results that are consistent with a backward-looking (traditional) Phillips curve. ${ }^{42}$

The choice of instruments can have a strong influence on the GMM estimates of the NPC and their significance. It is widely accepted that the test for overidentifying restrictions as a means to detect invalid instruments has low power. In addition, Bardsen, Jansen and Nymoen (2002), and Rudd and Whelan (2001) argue that the results can be significantly biased by using variables as instruments that actually belong in a well-specified inflation regression. Furthermore, if the forcing variable is regarded as endogenous then it should be instrumented in the estimation. Bardsen, Jansen and Nymoen (2002) argue that to derive the dynamic properties of inflation, we require an analysis of the system that includes the forcing variable as well as the rate of inflation, and conclude that "as statistical models, both the pure and hybrid NPC ${ }^{43}$ are inadequate".

In this context, it is important to keep in mind our theoretical argument (Section 4) that any forward-looking Phillips curve (containing leads) can be translated into a backward-looking one (containing only contemporaneous and lagged variables) by solving the macro model and expressing expectations of future inflation in terms of present and lagged variables. On this account, as well as the unresolved empirical issues above, the wage and price equations in our empirical model are specified solely in terms of current and past variables. (They can, however, be interpreted as the outcome of decisions by forward-looking agents, because these agents' expectations of the future depend on their information about current and past variables and the underlying stochastic processes.) Thus, the empirical wage and price equations may be

${ }^{42}$ Since rational expectations are also model consistent, they use repeated substitution to express the NPC as

$$
\pi_{t}=\beta^{k+1} E_{t} \pi_{t+k+1}+\gamma \sum_{j=0}^{k} \beta^{j} E_{t} x_{t+j} .
$$

The last term in the above equation is a present value term of the forcing variable and $\gamma$ is estimated using GMM.

${ }^{43}$ This point is consistent with our argument in Section 4 that inflation persistence in response to monetary shocks can only be evaluated in the context of a general equilibrium system including the Phillips curve, rather than through the Phillips curve alone.

The hybrid specification of the Phillips curve can be expressed as

$$
\pi_{t}=\beta^{b} \pi_{t-1}+\beta^{f} E_{t} \pi_{t+1}+\gamma x_{t} .
$$


seen at the counterparts of equations (4.3) and (4.4), respectively. ${ }^{44}$

We solve these three equations as a system and derive the implied inflation-unemployment tradeoff. This empirical exercise merely aims to illustrate how an estimated Phillips curve can be derived from equations describing the interplay between money growth and nominal frictions. The exercise is no more than a preliminary first step towards a full-blown empirical investigation, ${ }^{45}$ which lies well beyond the scope of this paper.

\subsection{Data and Estimation}

We use US annual time series data, obtained from the OECD and Datastream, covering the period 1966-2000. The definitions of the variables are given in Table 2.

\begin{tabular}{|c|c|c|c|}
\hline \multicolumn{4}{|c|}{ Table 2: Definitions of variables } \\
\hline$M_{t}:$ & money supply (M3) & $f w_{t}:$ & financial wealth $\left(\frac{\text { SP500 }}{\text { labor nroductivity }}\right)$ \\
\hline$P_{t}:$ & price level & & real oil price \\
\hline$W_{t}:$ & nominal wages & & real foreign demand (exports-imports) \\
\hline$u_{t}:$ & unemployment rate & & indirect taxes as a \% of GDP \\
\hline$p r_{t}:$ & real labor productivity & & real social security benefits \\
\hline $\begin{array}{l}m_{t}: \\
k_{t}:\end{array}$ & $\begin{array}{l}\text { real money balances }\left(M_{t}-P_{t}\right) \\
\text { real capital stock }\end{array}$ & $s s c_{t}:$ & real social security contributions \\
\hline
\end{tabular}

The price setting, wage setting, and unemployment rate equations of our model were initially estimated individually using the autoregressive distributed lag (ARDL) approach to cointegration analysis developed by Pesaran and Shin (1995), Pesaran (1997), and Pesaran et al. (1996). These papers argue that the traditional ARDL approach justified when regressors are I(0), can also be valid with $\mathrm{I}(1)$ regressors. An important implication of this methodology is that, since an ARDL equation can always be reparameterized in an error correction format, the long-run

\footnotetext{
${ }^{44}$ More precisely, the empircal model may be understood as a natural extension of our theoretical model to include staggered contracts of both wage and prices. Thus in our empirical model, past nominal values affect the current wage level differently from the current price level.

${ }^{45}$ Such an analysis would, for example, contain a wider range of explanatory variables (e.g. dividing the labor force into skilled and unskilled workers, distinguishing between productivity in different sectors of the economy, etc.), a larger number of equations (e.g. the unemployment rate could be derived from labor demand and labor supply equations, the capital stock could be endogenized, etc.), and so on. It would also examine the implications of GMM and 2SLS estimation of wage and price equations containing leads.
} 
solution of the ARDL can be interpreted as the cointegrating vector of the variables involved.

The dynamic specification of each equation was determined by the optimal lag-length algorithm of the Akaike and Schwarz information criteria. The selected estimated equations are dynamically stable (i.e., the roots of their autoregressive polynomia lie outside the unit circle), and pass the standard diagnostic tests (for no serial correlation, linearity, normality, homoskedasticity, and constancy of the parameters of interest) at conventional significance levels. ${ }^{46}$ In order to take into account potential endogeneity and cross equation correlation, we then estimated the equations as a system using three stages least squares (3SLS). These results are presented in Table $3 .{ }^{47}$ The model tracks the data very well. ${ }^{48}$

\begin{tabular}{|c|c|c|c|c|c|c|c|c|}
\hline \multicolumn{9}{|c|}{ Table 3: US model, 3SLS, 1966-2000. } \\
\hline & coef. & std. e. & & coef. & std. e. & & coef. & std. e. \\
\hline$u_{t-1}$ & 0.43 & $(0.12)$ & $P_{t-1}$ & 1.19 & $(0.13)$ & $W_{t-1}$ & 0.24 & $(0.10)$ \\
\hline$u_{t-2}$ & -0.30 & $(0.11)$ & $P_{t-2}$ & -0.54 & $(0.08)$ & $\Delta W_{t-2}$ & 0.48 & $(0.10)$ \\
\hline$m_{t}$ & -0.12 & $(0.03)$ & $W_{t-1}$ & 0.34 & $(0.10)$ & $P_{t}$ & 0.68 & $(0.09)$ \\
\hline$f d_{t}$ & -0.16 & $(0.05)$ & $M_{t}$ & 0.01 & $(*)$ & $M_{t}$ & 0.09 & $(*)$ \\
\hline$\Delta k_{t}$ & -0.01 & $(0.002)$ & $u_{t}$ & -0.72 & $(0.16)$ & $u_{t}$ & -0.41 & $(0.17)$ \\
\hline$o_{t-1}$ & 0.01 & $(0.003)$ & $p r_{t}$ & -0.30 & $(0.06)$ & $p r_{t}$ & 0.32 & $(0.09)$ \\
\hline$f w_{t}$ & -0.01 & $(0.005)$ & $o_{t}$ & 0.02 & $(0.004)$ & $b_{t}$ & 0.05 & $(0.02)$ \\
\hline \multirow[t]{3}{*}{$s s c_{t}$} & 0.04 & $(0.02)^{\prime}$ & $o_{t-1}$ & 0.01 & $(0.004)$ & & & \\
\hline & & & $o_{t-2}$ & -0.01 & $(0.003)$ & & & \\
\hline & & & $\tau_{t}$ & 0.02 & $(0.006)$ & & & \\
\hline
\end{tabular}

In the unemployment equation, product demand-side influences are captured through real money balances and financial wealth ${ }^{49}$ (affecting domestic demand), as well as net foreign demand. Product supply-side influences are captured through the oil price, capital accumulation, and social security contributions. Observe that the sum of the lagged dependent variable coefficients is small and positive, implying a low degree of unemployment persistence. Since the US unemployment rate is trendless, the explanatory variables in the unemployment equation need to be specified as non-trended series as well. On this account, real money balances, social security contributions and benefits, and foreign demand are normalized by working age population,

\footnotetext{
${ }^{46}$ See Karanassou, Sala and Snower (2002), Appendix 3.

${ }^{47}$ Constants and trends are omitted for brevity.

${ }^{48}$ The actual and fitted values of the estimated system are pictured in Karanassou, Sala and Snower (2002), Appendix 4.

${ }^{49}$ See Phelps (1999), Fitoussi et al. (2000), and Phelps and Zoega (2001).
} 
whereas financial wealth is deflated by productivity.

The price and wage equations are quite standard. ${ }^{50}$ Prices depend on wages and the money supply, and wages depend on prices and the money supply. Productivity has a positive effect on nominal wages and a negative effect on prices. The unemployment moderates the mark-up of prices on wages, and of wages on prices. The lag structure of our price and wage equations is consistent with our theoretical model. ${ }^{51}$ The restriction of no money illusion is imposed on the price and wage equations, so that each equation is homogeneous of degree zero in all nominal variables. Specifically, we restrict the coefficient of money in each of our nominal equations to be equal to one minus the coefficients of all nominal variables on the right-hand side of that equation. ${ }^{52}$ These restrictions could not be rejected at conventional significance levels.

\subsection{Empirical Impulse-Response Functions}

In this empirical context, we examine the influence of a money growth shock on inflation and unemployment through time. Specifically, suppose that the economy is initially in a steady state, with the money supply growing at the constant rate $\mu$. Then, at time $t=0$, the money growth rate increases by a fixed amount to $\mu^{\prime}$. This shock is unanticipated and may be interpretted as a single realization of the stochastic process generating the money supply. ${ }^{53}$ We derive the inflation and unemployment responses to this shock for time $t \geq 0 .{ }^{54}$

Figure 3 presents the impulse response functions (IRFs) that correspond to a $10 \%$ permanent

\footnotetext{
${ }^{50}$ In order for all variables in our price and wage equations to be integrated of the same order, the equations need to be reparameterized before estimation. For instance, consider the price equation in Table 3: $P_{t}=a_{0}+a_{1} P_{t-1}+a_{2} P_{t-2}+a_{3} W_{t-1}+\left(1-a_{1}-a_{2}-a_{3}\right) M_{t}+\beta^{\prime} x_{t}$, where $\beta^{\prime}$ is a row vector of parameters, and $x_{t}$ is a column vector of the real variables. The above can be reparameterized as $\left(P_{t}-M_{t}\right)=$ $a_{0}+a_{1}\left(P_{t-1}-M_{t-1}\right)+a_{2}\left(P_{t-2}-M_{t-2}\right)+a_{3}\left(W_{t-1}-M_{t-1}\right)-\left(a_{1}+a_{2}+a_{3}\right) \Delta M_{t}-a_{2} \Delta M_{t-1}+\beta^{\prime} x_{t}$. These two equations are statistically equivalent. We estimate our price equation using the latter equation, and present the Table 3 results in the format of the former equation. The analogous procedure is applied to the wage equation.

${ }^{51}$ In both the theoretical and empirical models, current wages and prices are explained in terms of past wages and prices and the current money supply. The empircal model may be understood as a natural extension of our theoretical model to include staggered contracts of both wage and prices. Thus in our empirical model, past nominal values affect the current wage level differently from the current price level.

${ }^{52}$ For example, the price equation in Table 3 (first equation in the previous footnote) is clearly homogeneous of degree zero in $M_{t}, P_{t}, P_{t-1}, P_{t-2}$, and $W_{t-1}$. The analogous restriction is imposed on the wage equation.

${ }^{53}$ Since the shock is a realization of the actual money growth process, this exercise does not run afoul of the Lucas critique.

${ }^{54}$ We assume that the future values of the exogenous variables are unaffected by the monetary shock (which is obvious, for otherwise these variables would not be exogenous). Thus, given the linearity of our model, the simulation is unaffected by these future variables.
} 
increase in the growth rate of money supply. The inflation IRF has all the desirable properties, namely, the influence of the monetary shock on inflation is delayed and gradual, and in the long run inflation is equal to money growth. The unemployment IRF also exhibits plausible behavior: the unemployment effect of the monetary shock is also delayed and gradual, but this effect occurs sooner than the inflation effect (e.g. the maximum unemployment effect occurs well before that on inflation.) Also observe that the inflation and unemployment responses take a long time to converge to their long-run values.

The only strikingly unconventional property of the unemployment IRF is that the unemployment effect does not die down to zero; rather, a 10 percent increase in money growth leads to a 2.73 percent fall in long-run unemployment. ${ }^{55}$ Thus, the slope of the long-run Phillips curve is $-3.66\left(=\frac{10}{-2.73}\right)$.

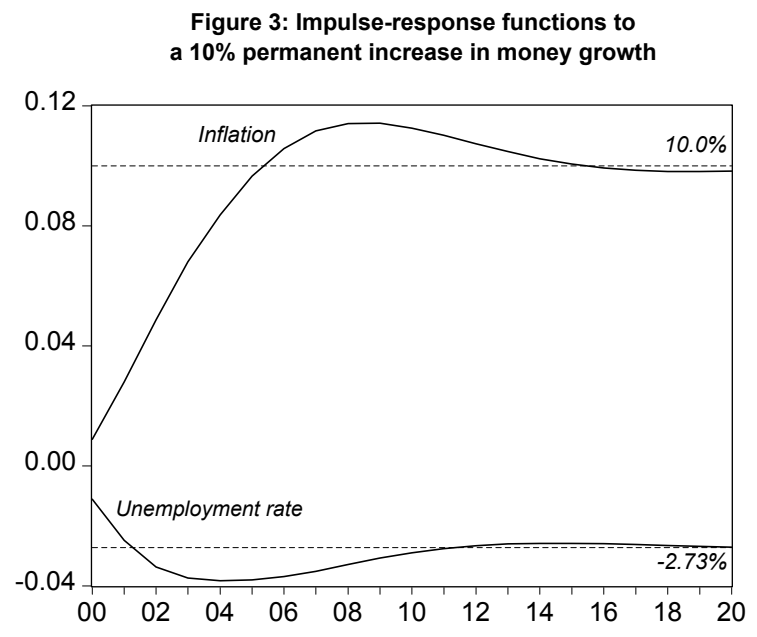

\subsection{Montecarlo Simulations}

To have confidence that our long-run Phillips curve is indeed not vertical, we need to examine whether our point estimate of the slope (-3.66) is significantly different from infinity. For this purpose, we perform the following Monte Carlo experiment, consisting of 1000 replications. In each replication $(i)$, a vector of error terms $\varepsilon_{t}^{(i)}=\left(\varepsilon_{u, t}^{(i)}, \varepsilon_{P, t}^{(i)}, \varepsilon_{W, t}^{(i)}\right)^{\prime}, t=1,2, \ldots, T$ (of the

\footnotetext{
${ }^{55}$ Also observe that the unemployment IRF overshoots substantially: the maximum effect on unemployment is nearly 4 percent.
} 
unemployment rate, price, and nominal wage equations, respectively) is drawn from the normal distribution, ${ }^{56} N\left(0, \sum\right)$. The vector $\varepsilon_{t}^{(i)}$ is then added to the vector of estimated equations to generate a new vector of endogenous variables $y_{t}^{(i)}=\left(u_{t}^{(i)}, P_{t}^{(i)}, W_{t}^{(i)}\right)$. Next, the equations of the model are estimated using the new vector of endogenous variables $y_{t}^{(i)}$, and the set of exogenous variables. Finally, the simulation exercise of the previous section is conducted on the newly estimated system to derive a new estimate of the slope of the long-run Phillips curve. In this way, each replication $(i)$ yields a new value for the slope: $S^{(i)}, i=1,2, \ldots, 1000$.

Figure 4 presents the histogram of the 1000 simulated values of the long-run Phillips curve slope. This shows clearly that the estimated slope of the long-run Phillips curve is indeed significantly downward-sloping and reasonably flat, rather than vertical. ${ }^{57}$

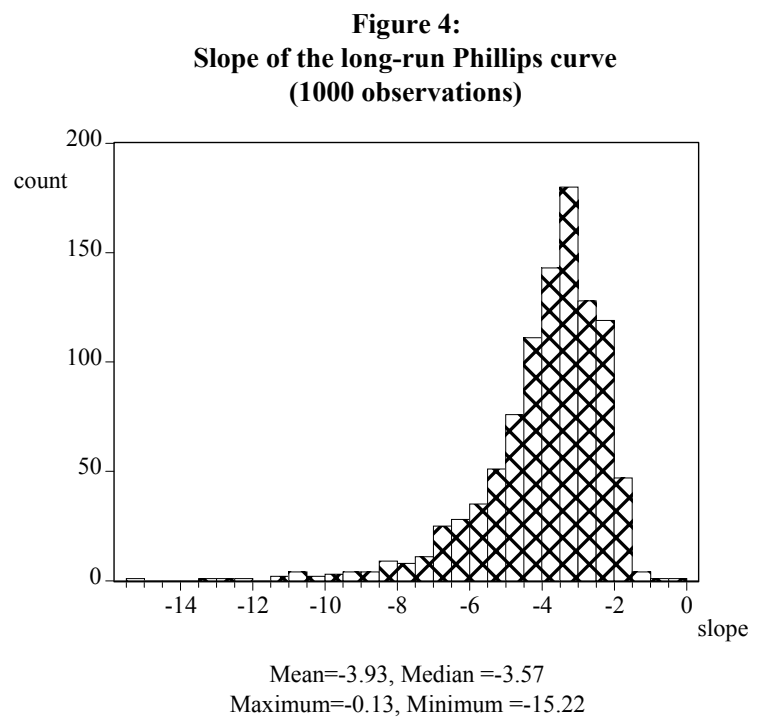

\section{Conclusions}

This paper offers a reappraisal of the inflation-unemployment tradeoff on the basis of frictional growth. While the choice between our analysis and the textbook New Phillips curve is an empirical issue, three of our results suggest that our approach is more closely in accord with the

\footnotetext{
${ }^{56}$ We used the normal distribution because the assumption of normality is valid in the estimated system of equations. $\left(\varepsilon_{t} \sim N\left(0, \sum\right)\right.$, where $\sum$ is the variance-covariance matrix of the estimated model.)

${ }^{57}$ See Karanassou, Sala and Snower (2002), Appendix 5 for further evidence in support of this result.
} 
established empirical regularities. First, in our analysis movements of inflation and unemployment do not have the knife-edge property; in fact the long-run Phillips curve may be reasonably flat. The available empirical evidence in the OECD does not support the view that inflation falls without limit when unemployment is above some stable NAIRU (implying a vertical longrun Phillips curve); nor does it appear to support the view that there is massive deflation when unemployment is high (implying that the long-run Phillips curve is very steep). Second, our analysis can explain how money growth shocks have a delayed and gradual effect on inflation, so that there is inflation persistence. Third, it shows that monetary shocks usually have a quicker effect on unemployment and the time path of this effect tends to be hump-shaped.

Inevitably, our analysis suggests a reevaluation of the role monetary policy in the macroeconomic system. It shows that since the effects of monetary policy on inflation and unemployment generally take a long time to work themselves out, we cannot expect close correlations between current money growth (on the one hand) and current inflation and unemployment (on the other), even though monetary policy may have a major influence on these variables over time. Significantly, our analysis indicates that monetary policy can have long-term effects on unemployment. Whether these effects are permanent (along a downward-sloping long-run Phillips curve) or very prolonged (slow adjustment to a near-vertical long-run Phillips curve), may make little observational difference. Indeed, our theoretical model indicates that, in response to variations in the real interest rate, steeper long-run Phillips curves are associated with slower adjustment.

These considerations can have far-reaching implications for our understanding of monetary policy effectiveness. To illustrate briefly, consider the puzzling U.S. macroeconomic developments of the 1990s, when the unemployment rate declined (after 1992) and inflation remained subdued even though the rate of money growth surged. Although our empirical model is merely illustrative of our approach and should not be viewed as a serious tool for evaluating monetary policy, it nevertheless points to a simple story consistent with the facts. Figure 5a depicts the time path of the actual unemployment rate against the one the unemployment rate would have followed, in our model, had money growth remained constant at its 1993 rate. The difference between these two time paths represents the unemployment effect that is attributable to money 
growth, as an accounting exercise. ${ }^{58}$ Figure 5 b illustrates the actual inflation rate against the simulated inflation rate under money growth fixed at its 1993 rate, so that the difference represents the inflation effect attributable to money growth. Finally, Figure $5 \mathrm{c}$ depicts the actual inflation rate against the simulated inflation rate under productivity growth fixed at its 1993 rate, so that the difference represents the inflation effect attributable to productivity growth.
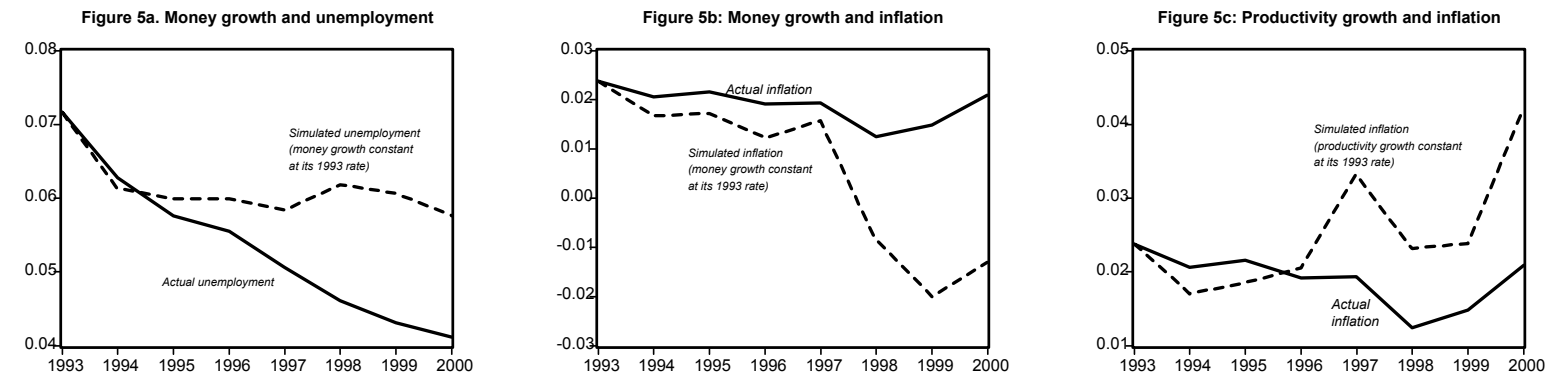

Although these figures are merely suggestive - even in our illustrative model, inflation and unemployment are explained by a lot more than just money growth and productivity growth - they make three simple points: First, the surge of money growth over the second half of the 1990s can account for about two thirds of the decline in unemployment over this period (Fig. 5a). Second, the money growth surge was of course associated with a rise in inflation (Fig. 5b). But, third, this inflationary influence was substantially undone by the fall in inflation associated with the increase in productivity growth over the period (Fig. 5c). This is of course a highly selective, impressionistic account of what happened, but it highlights some significant features of our analysis. In particular, since it can take a long time for the long-run inflation effect of a monetary growth shock to manifest itself, a surge in money growth need not be accompanied promptly by a surge in inflation. Inflation does not rise indefinitely when unemployment is low. Finally, monetary policy can have a long-term influence on unemployment and, over a period of half a decade or more, it is hard to tell whether this influence is permanent or prolonged, since the unemployment trajectory reflects the cumulative influence of lengthy impulse-response

\footnotetext{
${ }^{58}$ The money growth rate was less than 2 percent per annum in 1993, rose steadily to over 8 percent in 1998, before declining beneath 6 percent in 2000. Increased productivity growth is also associated with reduced unemployment in our model, but the influence is much weaker than that of money growth in our model.
} 
functions from an ongoing stream of monetary shocks. In any case, monetary policy may play a more important and durable role in the real economy, and with respect to unemployment in particular, than the mainstream theories allow for.

Our analysis is of course just a first step towards a thorough reevaluation of the inflationunemployment tradeoff in terms of frictional growth. Much remains to be done, both in exploring the microfoundations of time-contingent price adjustment and in building reliable empirical models of how monetary shocks affect real economic activity.

\section{References}

[1] Akerlof, G. A., W. T. Dickens, and G. L. Perry (1996), "The Macroeconomics of Low Inflation," Brookings Papers on Economics Activity, 1, 1-76.

[2] Akerlof, George A., W.T Dickens, and W.L. Perry (2000), "Near Rational Wage and Price Setting and the Long-Run Phillips Curve," Brookings Papers on Economic Activity, 1, $1-60$.

[3] Ascari, G. (2000), "Optimising Agents, Staggered Wages and Persistence in the Real Effects of Monetary Shocks," Economic Journal, 110, July, 664-686.

[4] Ball, L. (1994), "Credible Disinflation with Staggered Price Setting," American Economic Review, 84(1), March, 282-289.

[5] Ball, L. (1995), "Disinflation with Imperfect Credibility," Journal of Monetary Economics, 35(1), February, 5-23.

[6] Ball, L. (1997), "Disinflation and the NAIRU," in C.D. Romer and D.H. Romer, eds, Reducing Inflation: Motivation and Strategy, Chicago: University of Chicago Press.

[7] Ball, L. (1999), "Aggregate Demand and Long-Run Unemployment," Brookings Papers on Economic Activity, vol. 2, 189-25.

[8] Bardsen, G., E. Jansen, and R. Nymoen (2002), "The Empirical (Ir)relevance of the New Keynesian Phillips Curve," Norwegian University of Science and Technology, Working Paper Series No. 21/2002.

[9] Bergen, P. R. and R. C. Feenstra (2000), "Staggered Price Setting, Translog Preferences, and Endogenous Persistence," Journal of Monetary Economics, 45, 657-680.

[10] Bernanke, B., M. Gertler, and S. Gilchrist (2000), "The Financial Accelerator in a Quantitative Business Cycle Framework," in John Taylor and Michael Woodford, eds., Handbook of Macroeconomics, Amsterdam: North Holland, 2000, chapter 21.

[11] Bernanke, B. S., and I. Mihov (1998), "The Liquidity Effect and Long-Run Neutrality," NBER Working Paper No. 6608. 
[12] Blanchard, O., and L. Summers (1986), "Hysteresis and the European Unemployment Problem," NBER Macroconomics Annual, vol. 1, Cambridge, MA: MIT Press, 15-77.

[13] Blanchard, O., and S. Fischer (1989), Lectures in Macroeconomics, Cambridge, Massachusetts: MIT Press.

[14] Calvo, G. (1983), "Staggered Prices in a Utility-Maximizing Framework," Journal of Monetary Economics, 12, 383-398.

[15] Christiano, L. J., M. Eichenbaum, and C. Evans (2001), "Nominal Rigidities and the Dynamic Effects of a Shock to Monetary Policy," National Bureau of Economic Research, Working Paper No. 8403.

[16] Clarida, R., J. Gali, and M. Gertler (1999), "The Science of Monetary Policy: A New Keynesian Perspective," Journal of Economic Literature, 37, December, 1661-1707.

[17] Dolado, J. J., López-Salido, J. D., Vega, J. L. (2000): "Spanish Unemployment and Inflation Persistence: Are There Phillips Trade-Offs?", Spanish Economic Review, No. 2, pp. 267-291.

[18] Dotsey, M., R.G. King, and A.L. Wolman (1997), "Menu Costs, Staggered Price-Setting, and Elastic Facctor Supply," manuscript, Federal Reserve Bank of Richmond.

[19] Erceg, C. J., D. W. Henderson, and A. T. Levin (2000), "Optimal Monetary Policy with Staggered Wage and Price Contracts," Journal of Monetary Economics, 46, 281-313.

[20] Estrella, A., and J. C. Fuhrer (1998), "Dynamic Inconsistencies: Counterfactual Implications of a Class of Rational Expectations Models," mimeo.

[21] Fair, R. C. (2000), "Testing the NAIRU Model for the United States," The Review of Economics and Statistics, 82, 1, February, 64-71.

[22] Fitoussi, J.P., D. Jestaz, E.S Phelps and G. Zoega (2000): "Roots of the Recent Recoveries: Labor Reforms or Private Sector Forces?", Brookings Papers on Economic Activity, 1:2000, 237-311.

[23] Fuhrer, J. C., and G. R. Moore (1995), "Inflation Persistence," Quarterly Journal of Economics, 110, Feb., 127-159.

[24] Gali, J. (2002), "New Perspectives on Monetary Policy, Inflation and the Business Cycle," forthcoming in Advances in Economic Theory, edited by M. Dewatripont, L. Hansen, and S. Turnovsky, Cambridge: Cambridge University Press.

[25] Gali, Jordi, and Mark Gertler (1999), "Inflation Dynamics: A Structural Econometric Analysis," Journal of Monetary Economics, 44, 195-222.

[26] Gali, J., M. Gertler, and J. D. Lopez-Salido (2001), "European Inflation Dynamics," European Economic Review, 45, 1237-1270.

[27] Goodfriend, M., and R. G. King (1997), "The New Neoclassical Synthesis and the Role of Monetary Policy," NBER Macroeconomics Annual, Cambridge, Mass: MIT Press, 231-295. 
[28] Graham, L., and D. J. Snower (2002), "The Return of the Long-Run Phillips Curve," mimeo.

[29] Helpman, E., and L. Leiderman (1990), "Real Wages, Monetary Accommodation, and Inflation," European Economic Review, 34, 897-911.

[30] Henry, B., M. Karanassou, and D. Snower (2000), "Adjustment Dynamics and the Natural Rate", Oxford Economic Papers, 52, 178-203.

[31] Huang, K. X. D., Z. Liu (2001), "Production Chains and General Equilibrium Aggregate Dynamics," Journal of Monetary Economics, 48, 437-462.

[32] Huang, K. X.D., Z. Liu (2002), "Staggered Price-Setting, Staggered Wage Setting, and Business Cycle Persistence," Journal of Monetary Economics, 49, 405-433.

[33] Jeanne, O. (1998), "Generating Real Persistent Effects of Monetary Shocks: How Much Nominal Rigidity Do We Really Need?" European Economic Review, 42, 1009-1032.

[34] Karanassou, M., H. Sala, and D. Snower (2002), "A Reappraisal of the InflationUnemployment Tradeoff," CEPR Discussion Paper No. 3665 and IZA Discussion Paper No. 636.

[35] Kiley, M. T. (1997), "Staggered Price Setting and Real Rigidities," Federal Reserve Board, Finance and Economics Series Working Paper No. 1997-46.

[36] Kiley, M. T. (2002), "Partial Adjustment and Staggered Price Setting," Journal of Money, Credit and Banking, 34, 2, May, 283-298.

[37] King, R. G., and M. W. Watson (1994), "The Post-War U.S. Phillips Curve: A Revisionist Econometric History," Carnegie-Rochester Conference Series on Public Policy, 41, 157-219.

[38] Lindbeck, A., and D. J. Snower (1989), The Insider-Outsider Theory of Employment and Unemployment, Cambridge, Mass: MIT Press.

[39] Lindbeck, A., and D. J. Snower (1999), "Price Dynamics and Production Lags," American Economic Review, May, 89(2), 81-88.

[40] Mankiw, N. G. (2001): "The Inexorable and Mysterious Tradeoff between Inflation and Unemployment", The Economic Journal, 111, May, C45-C61.

[41] Mankiw, N. G., and R. Reis (2001), "Sticky Information versus Sticky Prices: A Proposal to Replace the New Keynesian Phillips Curve," National Bureau of Economic Research, Working Paper No. 8290.

[42] Pesaran , M. H., and Y. Shin (1995): "An ARDL Approach to Cointegration Analysis", Working Paper, n9514, Department of Applied Economics, University of Cambridge.

[43] Pesaran, M. H., Shin, Y. and Smith, R.J. (1996): "Testing for the existence of a Long-Run Relationship", Working Paper No. 9645, CREST, Institut National de la Statistique et des Etudes Economiques, Malakoff, France.

[44] Pesaran, M. H. (1997), "The Role of Economic Theory in Modelling the Long Run", The Economic Journal , 107(440), Jan., C178-C191. 
[45] Phelps, E. S. (1994), Structural Slumps: The Modern Equilibrium Theory of Unemployment, Interst and Assets, Cambridge, Mass: Harvard University Press.

[46] Phelps, E. S. (1999): "Behind this Structural Boom: The Role of Asset Valuations", American Economic Review, Papers and Proceedings, vol. 89, 2, May, 63-68.

[47] Phelps, E. and G. Zoega (2001): "Structural booms: productivity expectations and asset valuations", Economic Policy, 32, April, 85-126.

[48] Roberts, J. M. (1995): "New Keynesian Economics and the Phillips Curve," Journal of Money, Credit and Banking, 27(4,1), November, 975-984.

[49] Roberts, J. M. (1997), "Is Inflation Sticky?" Jounral of Monetary Economics, 39, 173-196.

[50] Romer, D. (1990), "Staggered Price Setting with Endogenous Frequency of Adjustment," Economics Letters, 32, 205-210.

[51] Romer, D. (1996), Advanced Macroeconomics, New York: McGraw Hill.

[52] Rotemberg, J. (1982), "Monopolistic Price Adjustment and Aggregate Output," Review of Economic Studies, 44, 517-531.

[53] Rudd, J. and K. Whelan, "New Tests of the New-Keynesian Phillips Curve", Federal Reserve Board, Working Paper.

[54] Sachs, J. (1980), "The Changing Cyclical Behavior of Wages and Prices: 1890-1976," American Economic Review, 70, 78-90.

[55] Taylor, J. B. (1979), "Staggered Wage Setting in a Macro Model," American Economic Review, 69, May, 108-113.

[56] Taylor, J. B. (1980a), "Aggregate Dynamics and Staggered Contracts," Journal of Political Economy, 88 (1), 1-23.

[57] Taylor, J. B. (1980b), "Output and Price Stability: An International Comparison," Journal of Economic Dynamics and Control, vol. 2, 109-132.

[58] Walsh, C. (1998), Monetary Theory and Policy, Cambridge, MA: MIT Press. 


\section{APPENDICES}

\section{Appendix 1a: Time-Series Properties of the Money Supply}

The following table presents the results of unit root tests on the US money supply. Observe that we cannot reject the hypothesis that the growth rate of money supply follows an $I(1)$ process at the $5 \%$ size of the test.

\begin{tabular}{|ccccc|}
\hline \multicolumn{4}{|c|}{ Table A1: Unit root tests, US money supply, 1966-2000 } \\
\hline & Dickey-Fuller & & Phillips-Perron & $5 \%$ critical value \\
\cline { 2 - 2 }$M_{t}$ & $\mathrm{ADF}_{(c, t)}=-0.77$ & $\mathrm{PP}_{(c, t)}=-0.35$ & -3.54 \\
$\Delta M_{t}$ & $\mathrm{ADF}_{(c)}=-2.80$ & $\mathrm{PP}_{(c)}=-2.72$ & -2.95 \\
$\Delta^{2} M_{t}$ & $\mathrm{ADF}=-7.40$ & $\mathrm{PP}=-7.55$ & -1.95 \\
\hline ADF $(c, t)$, and $\mathrm{PP}(c, t)$ denote the unit root tests with constant and trend. \\
The lag truncation for Bartlett kernel in the PP tests is three. \\
The order of augmentation in the ADF tests is one. \\
\hline
\end{tabular}

\section{Appendix 1b: Alternative Specification of the Money Supply Process}

Suppose that money growth $\mu_{t}$ follows a stationary autoregressive process and the monetary authority pursues the following mixed strategy: with probability $\rho$ it follows

$$
\mu_{t}=g+\psi_{1} \mu_{t-1}+\varepsilon_{t},
$$

and with probability $(1-\rho)$ it follows

$$
\mu_{t}=g+\psi_{2} \mu_{t-1}+\varepsilon_{t},
$$

where $\varepsilon_{t}$ is white noise, $0<\psi_{1}, \psi_{2}<1$, and $\psi_{1}<\psi_{2}$.

Thus the money supply rule is

$$
\mu_{t}=g+\xi \mu_{t-1}+\varepsilon_{t},
$$

where $\xi=\rho \psi_{1}+(1-\rho) \psi_{2}$.

Consequently the equilibrium nominal wage is given by ${ }^{1}$

$$
\begin{aligned}
W_{t} & =\left(1-\lambda_{1}\right) c+\lambda_{1} W_{t-1}+\left(1-\lambda_{1}\right) M_{t}-\left(1-\lambda_{1}\right) L \\
& +\sigma\left(1-\lambda_{1}\right) \mu_{t}+\left(\frac{1-\lambda_{1}}{1-\xi}\right)(\kappa-\sigma) g+\omega_{t},
\end{aligned}
$$

\footnotetext{
${ }^{1}$ The algebraic steps in the derivation of $W_{t}$ are given in Appendix 2.
} 
where ${ }^{2}$

$$
\sigma=\frac{\xi}{1-\xi}-\frac{\alpha \xi\left(\lambda_{2}-1\right)}{\left(\lambda_{2}-\xi\right)}-\frac{\xi^{2}\left(\lambda_{2}-1\right)}{(1-\xi)\left(\lambda_{2}-\xi\right)}>0 .
$$

The price equation is

$$
\begin{aligned}
P_{t} & =\left(1-\lambda_{1}\right) c+\lambda_{1} P_{t-1}+\left(1-\lambda_{1}\right) M_{t}-\left(1-\lambda_{1}\right) L \\
& +\left(\sigma-\frac{1}{2}\right)\left(1-\lambda_{1}\right) \mu_{t}+\left(\frac{1-\lambda_{1}}{1-\xi}\right)(\kappa-\sigma) g \\
& -\frac{1}{2} \sigma\left(1-\lambda_{1}\right) \varepsilon_{t}+\frac{1}{2}\left(\omega_{t}+\omega_{t-1}\right)
\end{aligned}
$$

The long-run solution of the first difference of above equation gives the longrun inflation rate:

$$
\pi_{t}^{L R}=\mu_{t}^{L R}=\frac{g}{1-\xi} .
$$

The real money balances equation is given by

$$
\begin{aligned}
M_{t}-P_{t} & =-\left(1-\lambda_{1}\right) c+\lambda_{1}\left(M_{t-1}-P_{t-1}\right)+\left(1-\lambda_{1}\right) L \\
& +\left[\frac{1}{2}\left(1+\lambda_{1}\right)-\sigma\left(1-\lambda_{1}\right)\right] \mu_{t}+\left(\frac{1-\lambda_{1}}{1-\xi}\right)(\sigma-\kappa) g \\
& +\frac{1}{2} \sigma\left(1-\lambda_{1}\right) \varepsilon_{t}-\frac{1}{2}\left(\omega_{t}+\omega_{t-1}\right) .
\end{aligned}
$$

The unemployment rate equation is

$$
\begin{aligned}
u_{t} & =\left(1-\lambda_{1}\right) c+\lambda_{1} u_{t-1}-\left[\frac{1}{2}\left(1+\lambda_{1}\right)-\sigma\left(1-\lambda_{1}\right)\right] \mu_{t} \\
& -\left(\frac{1-\lambda_{1}}{1-\xi}\right)(\sigma-\kappa) g-\frac{1}{2} \sigma\left(1-\lambda_{1}\right) \varepsilon_{t}+\frac{1}{2}\left(\omega_{t}+\omega_{t-1}\right) .
\end{aligned}
$$

The long-run unemployment rate is

$$
\begin{aligned}
u_{t}^{L R} & =c-\left[\frac{1}{2}\left(\frac{1+\lambda_{1}}{1-\lambda_{1}}\right)-\sigma\right] \mu_{t}-\left(\frac{\sigma-\kappa}{1-\xi}\right) g \\
& =c-\pi_{t}^{L R}\left(\frac{2 \alpha-1}{\gamma}\right) .
\end{aligned}
$$

where the long-run inflation rate is $\pi_{t}^{L R}=g /(1-\xi)$. Changes in the policy parameters $\rho, \psi_{1}$, and $\psi_{2}$ move the economy along this long-run Phillips curve by changing the parameter $\xi$.

\section{Appendix 2: Theoretical Model and Results}

\footnotetext{
${ }^{2} \kappa, \lambda_{1}, \lambda_{2}$ are given in Appendix 2 .
} 
Our model may be summarized as follows:

$$
\begin{aligned}
N_{t} & =Q_{t}^{S}, \\
L_{t} & =L, \\
u_{t} & =L-N_{t}, \\
Q_{t}^{D} & =M_{t}-P_{t}, \\
\Delta M_{t} & \equiv \mu_{t}=\mu_{t-1}+\varepsilon_{t}, \\
Q_{t}^{S} & =Q_{t}^{D}=Q_{t}, \\
P_{t} & =\frac{1}{2}\left(W_{t}+W_{t-1}\right), \\
\Gamma_{t} & =Q_{t}-L, \\
W_{t}=\alpha W_{t-1}+(1-\alpha) E_{t} W_{t+1} & +\gamma\left[c+\alpha \Gamma_{t}+(1-\alpha) E_{t} \Gamma_{t+1}\right]+\omega_{t},
\end{aligned}
$$

\section{1: Wage Equation}

Substitute (18) into (19) and use (14), (16), and (17) to get:

$$
\begin{aligned}
W_{t} & =\alpha W_{t-1}+(1-\alpha) E_{t} W_{t+1}+\gamma \alpha\left[M_{t}-\frac{1}{2}\left(W_{t}+W_{t-1}\right)\right] \\
& +\gamma(1-\alpha)\left[E_{t} M_{t+1}-\frac{1}{2}\left(E_{t} W_{t+1}+W_{t}\right)\right]+\gamma c-\gamma L+\omega_{t} .
\end{aligned}
$$

Apply the expectations operator $E_{t}$ on the above equation, recall that $E_{t}\left(\omega_{t}\right)=0$, collect terms together, so that

$$
\begin{aligned}
\phi_{1} E_{t} W_{t-1}-\phi_{2} E_{t} W_{t}+\phi_{3} E_{t} W_{t+1} & =-\gamma\left[\alpha E_{t} M_{t}+(1-\alpha) E_{t} M_{t+1}\right] \\
& -\gamma c+\gamma L
\end{aligned}
$$

where

$$
\phi_{1}=\alpha\left(1-\frac{\gamma}{2}\right), \phi_{2}=\left(1+\frac{\gamma}{2}\right), \phi_{3}=(1-\alpha)\left(1-\frac{\gamma}{2}\right)
$$

To obtain the rational expectations solution of the above eq. (21), we proceed as follows. Use the backward shift operator $B^{3}$ to rewrite (21); then

\footnotetext{
${ }^{3}$ Note that $B^{1}$ shifts the variable backward, where $B^{-1}$ shifts the variable forward, i.e.

$$
B\left[E_{t} W_{t}\right]=E_{t} W_{t-1} \text {, and } B^{-1}\left[E_{t} W_{t}\right]=E_{t} W_{t+1},
$$
}

where $E_{t}$ is in all cases the conditional expectation as of period $t$. 
multiply both sides of the resulting equation by $B$, divide both sides by $\phi_{3}$, and use $E_{t} W_{t}$ as a common factor on the L.H.S.:

$$
\left(1-\frac{\phi_{2}}{\phi_{3}} B+\frac{\phi_{1}}{\phi_{3}} B^{2}\right) E_{t} W_{t}=\frac{-B\left(E_{t} A_{t}\right)+\gamma L-\gamma c}{\phi_{3}},
$$

where

$$
E_{t} A_{t}=\gamma\left[\alpha E_{t} M_{t}+(1-\alpha) E_{t} M_{t+1}\right] .
$$

The $B$ polynomial in (23) can de expressed as

$$
\left(1-\frac{\phi_{2}}{\phi_{3}} B+\frac{\phi_{1}}{\phi_{3}} B^{2}\right)=\left(1-\lambda_{1} B\right)\left(1-\lambda_{2} B\right),
$$

where $\lambda_{1,2}$ are the roots of the equation

$$
\lambda^{2}-\frac{\phi_{2}}{\phi_{3}} \lambda+\frac{\phi_{1}}{\phi_{3}}=0,
$$

i.e.

$$
\begin{gathered}
\lambda_{1,2}=\frac{\frac{\phi_{2}}{\phi_{3}} \mp \sqrt{\left(\frac{\phi_{2}}{\phi_{3}}\right)^{2}-4\left(\frac{\phi_{1}}{\phi_{3}}\right)}}{2}, \text { so } \\
\lambda_{1}+\lambda_{2}=\frac{\phi_{2}}{\phi_{3}} \text {, and } \lambda_{1} \lambda_{2}=\frac{\phi_{1}}{\phi_{3}} \Rightarrow \lambda_{2}=\frac{\alpha}{\lambda_{1}(1-\alpha)} .
\end{gathered}
$$

It can be shown that one root lies inside the unit circle and the other outside the unit circle. In particular, we can show that when $0<\gamma<2$ then $0<\lambda_{1}<1$ and $\lambda_{2}>1$.

We can rewrite (23) using (25) as

$$
\left(1-\lambda_{1} B\right) E_{t} W_{t}=\frac{\gamma(c-L)}{\phi_{3}\left(\lambda_{2}-1\right)}-\frac{B\left(E_{t} A_{t}\right)}{\phi_{3}\left(1-\lambda_{2} B\right)} .
$$

Since $\left|\lambda_{2}\right|>1$, a useful way to express the geometric polynomial $1 /\left(1-\lambda_{2} B\right)$ is as follows: 4

$$
\frac{1}{1-\lambda_{2} B}=\frac{-\left(\lambda_{2} B\right)^{-1}}{1-\left(\lambda_{2} B\right)^{-1}} .
$$

Substitute the above into (27) to get:

$$
\begin{aligned}
\left(1-\lambda_{1} B\right) E_{t} W_{t} & =\frac{\gamma(c-L)}{\phi_{3}\left(\lambda_{2}-1\right)}+\frac{E_{t} A_{t}}{\lambda_{2} \phi_{3}\left(1-\lambda_{2}^{-1} B^{-1}\right)} \\
& =\frac{\gamma(c-L)}{\phi_{3}\left(\lambda_{2}-1\right)}+\frac{1}{\lambda_{2} \phi_{3}} \sum_{j=0}^{\infty}\left(\frac{1}{\lambda_{2}}\right)^{j} E_{t} A_{t+j}
\end{aligned}
$$

\footnotetext{
${ }^{4}$ See Sargent (1987).
} 
or, using (24) and (15),

$$
\left(1-\lambda_{1} B\right) E_{t} W_{t}=\frac{\gamma(c-L)}{\phi_{3}\left(\lambda_{2}-1\right)}+\frac{\gamma}{\lambda_{2} \phi_{3}} \sum_{j=0}^{\infty}\left(\frac{1}{\lambda_{2}}\right)^{j}\left(E_{t} M_{t+1+j}-\alpha E_{t} \mu_{t+1+j}\right) .
$$

Further algebraic manipulation leads to

$$
\begin{aligned}
\left(1-\lambda_{1} B\right) E_{t} W_{t} & =\frac{\gamma(c-L)}{\phi_{3}\left(\lambda_{2}-1\right)}+\frac{\gamma}{\lambda_{2} \phi_{3}}\left[\frac{\lambda_{2} M_{t}}{\lambda_{2}-1}-\frac{\alpha \lambda_{2} \mu_{t}}{\lambda_{2}-1}+\frac{\lambda_{2}^{2} \mu_{t}}{\left(\lambda_{2}-1\right)^{2}}\right] \\
& =\left(1-\lambda_{1}\right)\left[c+M_{t}+\kappa \mu_{t}-L\right],
\end{aligned}
$$

where ${ }^{5}$

$$
\kappa=\frac{\lambda_{2}}{\lambda_{2}-1}-\alpha=\frac{\alpha\left(1+\lambda_{1}\right)(1-\alpha)}{\alpha-\lambda_{1}(1-\alpha)} .
$$

(It can be shown that $\kappa>0$.) So we have

$$
\left(1-\lambda_{1} B\right) E_{t} W_{t}=\left(1-\lambda_{1}\right) c+\left(1-\lambda_{1}\right) M_{t}+\kappa\left(1-\lambda_{1}\right) \mu_{t}-\left(1-\lambda_{1}\right) L .
$$

A comparison of the above eq. with (19) indicates that the rational expectations reduced-form stochastic difference equation for the wage is ${ }^{6}$

$$
W_{t}=\left(1-\lambda_{1}\right) c+\lambda_{1} W_{t-1}+\left(1-\lambda_{1}\right) M_{t}+\kappa\left(1-\lambda_{1}\right) \mu_{t}-\left(1-\lambda_{1}\right) L+\omega_{t} .
$$

Note that the above is the wage equation given in the text. (In the text the stable root $\lambda_{1}$ is denoted by $\lambda$ for simplicity.)

\section{2: Price Equation}

To derive the equation for the price dynamics rewrite the price equation (17) as follows:

$$
\left(1-\lambda_{1} B\right) P_{t}=\frac{1}{2}\left(1-\lambda_{1} B\right) W_{t}+\frac{1}{2}\left(1-\lambda_{1} B\right) W_{t-1},
$$

and substitute into it the wage equation (31). In the resulting equation, substitute the following expressions (implied by the money supply process $(15))$ :

$$
M_{t-1}=M_{t}-\mu_{t}, \text { and } \mu_{t-1}=\mu_{t}-\varepsilon_{t} \text {. }
$$

\footnotetext{
${ }^{5}$ Note that

$$
\left(\lambda_{2}-1\right)\left(1-\lambda_{1}\right)=\frac{\gamma}{\phi_{3}}
$$

so

$$
\frac{\gamma}{\phi_{3}\left(\lambda_{2}-1\right)}=\left(1-\lambda_{1}\right)
$$

${ }^{6}$ For the solution of linear difference equations under rational expectations see also Blanchard and Kahn (1980), and Sargent (1987).
} 
Next, collect terms together to get the price equation given in the text: ${ }^{7}$

$$
\begin{aligned}
\left(1-\lambda_{1} B\right) P_{t} & =\left(1-\lambda_{1}\right) c+\left(1-\lambda_{1}\right) M_{t}+\left(1-\lambda_{1}\right)\left(\kappa-\frac{1}{2}\right) \mu_{t}-\frac{1}{2} \kappa\left(1-\lambda_{1}\right) \varepsilon_{t} \\
& -\left(1-\lambda_{1}\right) L+\frac{1}{2}\left(\omega_{t}+\omega_{t-1}\right) .
\end{aligned}
$$

\section{3: Inflation Rate Equation}

Let the inflation rate be $\pi_{t} \equiv \Delta P_{t}$, and take the first difference of the price dynamics eq. (32) to obtain the inflation dynamics equation:

$$
\begin{aligned}
\left(1-\lambda_{1} B\right) \pi_{t} & =\left(1-\lambda_{1}\right) \mu_{t}+\frac{1}{2}\left(1-\lambda_{1}\right)(\kappa-1) \varepsilon_{t} \\
& +\frac{1}{2} \kappa\left(1-\lambda_{1}\right) \varepsilon_{t-1}+\frac{1}{2}\left(\omega_{t}-\omega_{t-2}\right) .
\end{aligned}
$$

\section{4: Real Money Balances}

To obtain the real money balances equation we do the following. Add and subtract on the R.H.S. of the price equation (32) the term $\lambda_{1} M_{t-1}$, and then rearrange terms so that

$$
\begin{aligned}
\left(1-\lambda_{1} B\right)\left(M_{t}-P_{t}\right) & =\left[\frac{1}{2}\left(1+\lambda_{1}\right)-\kappa\left(1-\lambda_{1}\right)\right] \mu_{t}+\frac{1}{2} \kappa\left(1-\lambda_{1}\right) \varepsilon_{t} \\
& +\left(1-\lambda_{1}\right) L-\frac{1}{2}\left(\omega_{t}+\omega_{t-1}\right)-\left(1-\lambda_{1}\right) c .
\end{aligned}
$$

Note that

$$
\left[\frac{1}{2}\left(1+\lambda_{1}\right)-\kappa\left(1-\lambda_{1}\right)\right]=\left(1-\lambda_{1}\right)\left(\frac{2 \alpha-1}{\gamma}\right) .
$$

Thus we obtain the real money balances equation given in the text:

$$
\begin{aligned}
\left(1-\lambda_{1} B\right)\left(M_{t}-P_{t}\right) & =-\left(1-\lambda_{1}\right) c+\left(1-\lambda_{1}\right)\left(\frac{2 \alpha-1}{\gamma}\right) \mu_{t} \\
& +\frac{1}{2} \kappa\left(1-\lambda_{1}\right) \varepsilon_{t}+\left(1-\lambda_{1}\right) L-\frac{1}{2}\left(\omega_{t}+\omega_{t-1}\right) .
\end{aligned}
$$

\footnotetext{
${ }^{7}$ Note that $\kappa>\frac{1}{2}$ if $\frac{2 \alpha+1}{2 \alpha-1}>\lambda_{2}$.
} 


\section{5: Output, Employment, and Unemployment}

Rewrite the aggregate demand equation (14) as

$$
\left(1-\lambda_{1} B\right) Q_{t}=\left(1-\lambda_{1} B\right)\left(M_{t}-P_{t}\right) .
$$

To obtain the dynamics for aggregate demand, substitute into the above equation the real money balances equation (36):

$$
\begin{aligned}
\left(1-\lambda_{1} B\right) Q_{t} & =\left(1-\lambda_{1}\right)\left(\frac{2 \alpha-1}{\gamma}\right) \mu_{t}-\left(1-\lambda_{1}\right) c \\
& +\frac{1}{2} \kappa\left(1-\lambda_{1}\right) \varepsilon_{t}+\left(1-\lambda_{1}\right) L-\widetilde{\omega}_{t} .
\end{aligned}
$$

Multiplying both sides of the production function (11) by $\left(1-\lambda_{1} B\right)$, we obtain

$$
\left(1-\lambda_{1} B\right) N_{t}=\left(1-\lambda_{1} B\right) Q_{t} .
$$

Substituting (37) into the above, we derive the employment dynamics equation:

$$
\begin{aligned}
\left(1-\lambda_{1} B\right) N_{t} & =\left(1-\lambda_{1}\right)\left(\frac{2 \alpha-1}{\gamma}\right) \mu_{t}-\left(1-\lambda_{1}\right) c \\
& +\frac{1}{2} \kappa\left(1-\lambda_{1}\right) \varepsilon_{t}+\left(1-\lambda_{1}\right) L-\widetilde{\omega}_{t} .
\end{aligned}
$$

The labour supply (12) equation may be expressed as

$$
\left(1-\lambda_{1} B\right) L=\left(1-\lambda_{1}\right) L .
$$

By the unemployment rate (13), the dynamic process for unemployment is the difference between the labor force (39) and employment (38). Thus we obtain the unemployment rate equation given in the text:

$$
\begin{aligned}
\left(1-\lambda_{1} B\right) u_{t} & =\left(1-\lambda_{1}\right) c-\left(1-\lambda_{1}\right)\left(\frac{2 \alpha-1}{\gamma}\right) \mu_{t} \\
& -\frac{1}{2} \kappa\left(1-\lambda_{1}\right) \varepsilon_{t}+\frac{1}{2}\left(\omega_{t}+\omega_{t-1}\right) .
\end{aligned}
$$

\section{6: Short-Run Phillips Curve}

Rewrite the unemployment eq. (40) and inflation eq. (33) as

$$
\begin{aligned}
& \left(1-\lambda_{1} B\right) u_{t}=\left(1-\lambda_{1}\right) c-\beta_{1} \mu_{t}-\beta_{2} \varepsilon_{t}+\frac{1}{2}\left(\omega_{t}+\omega_{t-1}\right), \\
& \left(1-\lambda_{1} B\right) \pi_{t}=\delta_{1} \mu_{t}+\delta_{2} \varepsilon_{t}+\beta_{2} \varepsilon_{t-1}+\frac{1}{2}\left(\omega_{t}-\omega_{t-2}\right),
\end{aligned}
$$


where

$$
\begin{aligned}
& \beta_{1}=\left(1-\lambda_{1}\right)\left(\frac{2 \alpha-1}{\gamma}\right), \beta_{2}=\frac{1}{2} \kappa\left(1-\lambda_{1}\right), \\
& \delta_{1}=1-\lambda_{1}, \delta_{2}=\frac{1}{2}\left(1-\lambda_{1}\right)(\kappa-1) .
\end{aligned}
$$

Now substitute the money supply eq. (15): $(1-B) \mu_{t}=\varepsilon_{t}$ into (41) and (42) to get

$$
\begin{aligned}
& \left(1-\lambda_{1} B\right) u_{t}=\left(1-\lambda_{1}\right) c-\beta_{1} \mu_{t}-\beta_{2}(1-B) \mu_{t}+\frac{1}{2}\left(\omega_{t}+\omega_{t-1}\right), \\
& \left(1-\lambda_{1} B\right) \pi_{t}=\delta_{1} \mu_{t}+\delta_{2}(1-B) \mu_{t}+\beta_{2}\left(B-B^{2}\right) \mu_{t}+\frac{1}{2}\left(\omega_{t}-\omega_{t-2}\right) .
\end{aligned}
$$

Express the (43) in terms of $\mu_{t}$ :

$$
\mu_{t}=\frac{\left(1-\lambda_{1} B\right) u_{t}-\left(1-\lambda_{1}\right) c-\frac{1}{2}\left(\omega_{t}+\omega_{t-1}\right)}{\beta(B)},
$$

where $\beta(B)=\left[-\left(\beta_{1}+\beta_{2}\right)+\beta_{2} B\right]$.

Substitution of (45) into (44) leads to the short-run Phillips curve

$$
\begin{aligned}
\left(1-\lambda_{1} B\right) \beta(B) \pi_{t} & =\left(1-\lambda_{1} B\right) \delta(B) u_{t}-\delta(B)\left(1-\lambda_{1}\right) c \\
& +\frac{\beta(B)\left(\omega_{t}-\omega_{t-2}\right)-\delta(B)\left(\omega_{t}+\omega_{t-1}\right)}{2}, \text { or } \\
\beta(B) \pi_{t} & =\delta(B) u_{t}-\delta_{1} c+\frac{\beta(B)\left(\omega_{t}-\omega_{t-2}\right)-\delta(B)\left(\omega_{t}+\omega_{t-1}\right)}{2\left(1-\lambda_{1} B\right)},
\end{aligned}
$$

where $\delta(B)=\left[\left(\delta_{1}+\delta_{2}\right)+\left(\beta_{2}-\delta_{2}\right) B-\beta_{2} B^{2}\right]$.

After some algebraic manipulation, the above short-run Phillips curve can be written as

$\pi_{t}=\frac{1}{\beta_{1}+\beta_{2}}\left[\left(1-\lambda_{1}\right) c+\beta_{2} \pi_{t-1}-\left(\delta_{1}+\delta_{2}\right) u_{t}-\left(\beta_{2}-\delta_{2}\right) u_{t-1}+\beta_{2} u_{t-2}\right]+e_{t}$,

where

$$
e_{t}=\frac{\widetilde{\omega}_{t}}{\left(1-\lambda_{1} B\right)}, \text { and } \widetilde{\omega}_{t}=\frac{\delta(B)\left(\omega_{t}+\omega_{t-1}\right)-\beta(B)\left(\omega_{t}-\omega_{t-2}\right)}{2\left(\beta_{1}+\beta_{2}\right)} .
$$

Through some algebraic manipulation we get:

$$
\begin{aligned}
\pi_{t} & =\frac{1}{\beta_{1}+\beta_{2}}\left[\left(1-\lambda_{1}\right) c+\beta_{2} \pi_{t-1}-\left(\delta_{1}+\delta_{2}\right) u_{t}-\left(\beta_{2}-\delta_{2}\right) u_{t-1}+\beta_{2} u_{t-2}\right]+e_{t} \\
& =\left(\frac{1-\lambda_{1}}{\beta_{1}+\beta_{2}}\right)\left[c+\frac{1}{2} \kappa \pi_{t-1}-\frac{1}{2}(1+\kappa) u_{t}-\frac{1}{2} u_{t-1}+\frac{1}{2} \kappa u_{t-2}\right]+e_{t} \\
& =\psi\left[c+\frac{1}{2} \kappa \pi_{t-1}-\frac{1}{2}(1+\kappa) u_{t}-\frac{1}{2} u_{t-1}+\frac{1}{2} \kappa u_{t-2}\right]+e_{t},
\end{aligned}
$$


where $^{8} \psi=\frac{1-\lambda_{1}}{\beta_{1}+\beta_{2}}$. In addition, the error term can be written as

$e_{t}=\frac{\widetilde{\omega}_{t}}{\left(1-\lambda_{1} B\right)}, \widetilde{\omega}_{t}=\frac{1}{2}\left[\left(1+\frac{\psi(1+\kappa)}{2}\right) \omega_{t}+\frac{3 \psi}{2} \omega_{t-1}-\left(1+\frac{\psi(\kappa-1)}{2}\right) \omega_{t-2}\right]$.

Note that the above error term is a moving average process in terms of $\omega_{t}$, with parameters which are non-linear functions of the theoretical parameters $\psi, \kappa$, and $\lambda_{1} \cdot{ }^{9}$

Express equation (46) as

$$
\pi_{t}=d_{0}+d_{1} \pi_{t-1}-d_{2} u_{t}-d_{3} u_{t-1}+d_{4} u_{t-2}+e_{t},
$$

where

$$
d_{0}=\psi c, d_{1}=\frac{\psi \kappa}{2}, d_{2}=\frac{\psi(1+\kappa)}{2}, d_{3}=\frac{\psi}{2}, d_{4}=\frac{\psi \kappa}{2} .
$$

Thus we have the following relationships among the $d$ 's:

$$
d_{4}=d_{1}, \text { and } d_{3}=d_{2}-d_{1} .
$$

Alternatively, (48) can be written as

$$
\left(1-\lambda_{1} B\right)\left(1-d_{1} B\right) \pi_{t}=d_{0}\left(1-\lambda_{1}\right)-\left(1-\lambda_{1} B\right)\left(d_{2}+d_{3} B-d_{4} B^{2}\right) u_{t}+\widetilde{\omega}_{t} .
$$

Recall that both the autoregressive and moving average parameters in the above Phillips curve equation are functions of the only two theoretical parameters $\alpha$ and $\gamma$. It is useful to have an overall picture of all the relationships among the parameters of the above short-run PC:

$$
\begin{aligned}
d_{0} & =\psi c, d_{1}=\frac{\psi \kappa}{2}, d_{2}=\frac{\psi(1+\kappa)}{2}, d_{3}=\frac{\psi}{2}, d_{4}=\frac{\psi \kappa}{2}, \\
\psi & =\frac{2 \alpha-1}{\gamma}+\frac{\kappa}{2}, \kappa=\frac{\alpha\left(1+\lambda_{1}\right)}{\frac{\alpha}{1-\alpha}-\lambda_{1}}, \lambda_{1}=\frac{\frac{\phi_{2}}{\phi_{3}}-\sqrt{\left(\frac{\phi_{2}}{\phi_{3}}\right)^{2}-4\left(\frac{\phi_{1}}{\phi_{3}}\right)}}{2}, \\
\phi_{1} & =\alpha\left(1-\frac{\gamma}{2}\right), \phi_{2}=\left(1+\frac{\gamma}{2}\right), \phi_{3}=(1-\alpha)\left(1-\frac{\gamma}{2}\right), \text { and } \\
\widetilde{\omega}_{t} & =\frac{1}{2}\left[\left(1+\frac{\psi(1+\kappa)}{2}\right) \omega_{t}+\frac{3 \psi}{2} \omega_{t-1}-\left(1+\frac{\psi(\kappa-1)}{2}\right) \omega_{t-2}\right] .
\end{aligned}
$$

The above equations make it clear that the restrictions we need to impose on the parameters of the short-run PC (50) are highly complicated non-linear functions of the theoretical underlying parameters $\alpha$ and $\gamma$. Therefore, (50) may not be estimable.

\footnotetext{
${ }^{8}$ Note that $\frac{\beta_{1}+\beta_{2}}{1-\lambda_{1}}=\frac{2 \alpha-1}{\gamma}+\frac{\kappa}{2}$.

${ }^{9}$ Recall that $\psi, \kappa$, and $\lambda_{1}$ are non-linear functions of the theoretical parameters $\alpha$ and $\gamma$ of the wage contract equation.
} 


\section{7: Long-Run Unemployment, Inflation, and the Phillips Curve}

To get the long-run solution of the unemployment equation (40) we set the backshift operator equal to unity $(B=1)$, and set equal to zero all the error terms ( $\varepsilon$ 's, $\omega$ 's). This gives us the following long-run:

$$
u_{t}^{L R}=-\left(\frac{2 \alpha-1}{\gamma}\right) \mu_{t}^{L R}+c .
$$

Similarly, the long-run solution of the inflation equation (33) is given by

$$
\pi_{t}^{L R}=\mu_{t}^{L R}
$$

To get the long-run Phillips curve we need to substitute (52) into (51):

$$
\pi_{t}^{L R}=-\left(\frac{\gamma}{2 \alpha-1}\right) u_{t}^{L R}+\left(\frac{\gamma}{2 \alpha-1}\right) c
$$

\section{8: Short-Run vs Long-Run Phillips Curve}

The slope of the short-run Phillips curve (46) is

$$
\frac{\partial \pi_{t}}{\partial u_{t}}=-\frac{\delta_{1}+\delta_{2}}{\beta_{1}+\beta_{2}}=-\frac{\gamma+\gamma \kappa}{2(2 \alpha-1)+\gamma \kappa},
$$

whereas the slope of the long-run Phillips curve (??) is

$$
\frac{\partial \pi_{t}^{L R}}{\partial u_{t}^{L R}}=-\frac{\gamma}{2 \alpha-1} .
$$

It can be shown that if the (absolute value of the) long-run slope is greater than unity then

$$
\left|\frac{\partial \pi_{t}^{L R}}{\partial u_{t}^{L R}}\right|>\left|\frac{\partial \pi_{t}}{\partial u_{t}}\right|
$$

i.e. the long-run PC is steeper than the short run PC. ${ }^{10}$

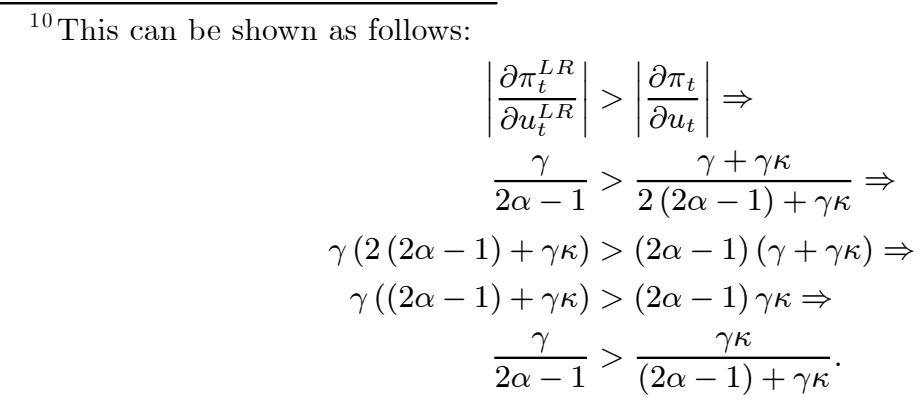

Since the smallest value that $\alpha$ is assumed to take is one half, it follows that the maximum value of right-hand side of the above inequality is unity. Therefore, we can say that a sufficient (but not necessary) condition for $\left|\frac{\partial \pi_{t}^{L R}}{\partial u_{t}^{L R}}\right|>\left|\frac{\partial \pi_{t}}{\partial u_{t}}\right|$ is that $\left|\frac{\partial \pi_{t}^{L R}}{\partial u_{t}^{L R}}\right|>1$. 
The intercept of the short-run Phillips curve (46) is

$$
\left(\frac{1-\lambda_{1}}{\beta_{1}+\beta_{2}}\right) c=\left(\frac{2 \gamma}{2(2 \alpha-1)+\gamma \kappa}\right) c>0,
$$

and the intercept of the long-run Phillips curve (53) is

$$
\left(\frac{\gamma}{2 \alpha-1}\right) c>0
$$

Since both $\gamma$ and $\kappa$ are positive, it is not difficult to see that the intercept of the long-run PC is greater than the intercept of the short-run PC:

$$
\left(\frac{\gamma}{2 \alpha-1}\right) c>\left(\frac{2 \gamma}{2(2 \alpha-1)+\gamma \kappa}\right) c
$$

\section{9: Impulse Response Functions}

We assume a one-off unit shock in the money growth process (15) which occurs at time $t=0: \varepsilon_{0}=1, \varepsilon_{t}=0$ for $t \neq 0$.

\section{9a: Inflation Rate}

The impulse response function of the inflation eq. (33) is given by

$$
\begin{aligned}
R\left(\pi_{0}\right) & =1+\frac{1}{2}\left[\left(1-\lambda_{1}\right) \kappa-\left(1+\lambda_{1}\right)\right]<1 \text { if } \kappa<\underbrace{\frac{1+\lambda_{1}}{1-\lambda_{1}}}_{\text {critical value } b_{2}}, \\
R\left(\pi_{t}\right) & =1+\lambda_{1}^{t-1}\left(\frac{1+\lambda_{1}}{2}\right)\left[\left(1-\lambda_{1}\right) \kappa-\lambda_{1}\right]<1 \text { if } \kappa<\underbrace{\frac{\lambda_{1}}{1-\lambda_{1}}}_{\text {critical value } b_{1}}, \\
R\left(\pi_{L R}\right) & \equiv \lim _{t \rightarrow \infty} R\left(\pi_{t}\right)=1, \text { (long-run response). }
\end{aligned}
$$

Observe that, since $\lambda_{1}<1$, we have that

$$
\left|R(\pi)_{t+1}-1\right|<\left|R(\pi)_{t}-1\right|, t \geq 1,
$$

i.e., period 1 onwards, inflation gradually approaches its new long-run value. ${ }^{11}$

\footnotetext{
${ }^{11}$ The effect of time on the inflation responses is given by

$$
\frac{\partial R(\pi)_{t}}{\partial t}=\lambda_{1}^{t-1}\left(\frac{1+\lambda_{1}}{2}\right)\left[\left(1-\lambda_{1}\right) \kappa-\lambda_{1}\right] \ln \lambda_{1}, t \geq 1 .
$$

So when $\kappa<\frac{\lambda_{1}}{1-\lambda_{1}} \Leftrightarrow\left[\left(1-\lambda_{1}\right) \kappa-\lambda_{1}\right]<0$, then the above derivative is positive, since $\ln \lambda_{1}<0$.
} 
We should note that, since $\frac{1}{2}<\alpha<1$, we cannot have that $\kappa$ is greater than $b_{2}$. That is, inflation cannot overshoot at the period that the shock is initiated $(t=0) .{ }^{12}$

\section{9b: Unemployment Rate} by ${ }^{13}$

The impulse response function of the unemployment eq. (40) is given

$$
\begin{gathered}
R\left(u_{t}\right)=-\left(\frac{2 \alpha-1}{\gamma}\right)-\frac{\lambda_{1}^{t}\left(1+\lambda_{1}\right)}{2\left(1-\lambda_{1}\right)}\left[\left(1-\lambda_{1}\right) \kappa-\lambda_{1}\right], \\
R\left(u_{L R}\right) \equiv \lim _{t \rightarrow \infty} R\left(u_{t}\right)=-\left(\frac{2 \alpha-1}{\gamma}\right), \text { (long-run response). }
\end{gathered}
$$

Closer inspection of the above equations reveals the following pattern for unemployment responses:

$$
\text { if } \kappa>\underbrace{\frac{\lambda_{1}}{1-\lambda_{1}}}_{\text {critical value } b_{1}} \text { then } \underbrace{R\left(u_{t}\right)<-\left(\frac{2 \alpha-1}{\gamma}\right)}_{\text {overshooting }} \text {, for } t \geq 0 \text {. }
$$

\begin{tabular}{|c|c|c|c|}
\hline \multicolumn{4}{|c|}{ Inflation - Unemployment Responses } \\
\hline Class I & $\kappa<b_{1}$ & $:$ & $\begin{array}{c}\underbrace{\pi_{t}<\pi_{L R}}_{\text {undershooting }}, \text { for } t \geq 0 \\
\underbrace{\left|u_{t}\right|<\left|u_{L R}\right|}_{\text {undershooting }}, \text { for } t \geq 0\end{array}$ \\
\hline Class II & $b_{1}<\kappa<b_{2}$ & $: \quad \pi_{0}<\pi_{L R}$ & $\begin{array}{c}\underbrace{\pi_{t}>\pi_{L R}}_{\text {overshooting }}, \text { for } t \geq 1 \\
\underbrace{\left|u_{t}\right|<\left|u_{L R}\right|}_{\text {overshooting }}, \text { for } t \geq 0\end{array}$ \\
\hline
\end{tabular}

The following table summarizes how inflation and unemployment respond to the above unit shock initiated at period $t=0$ :

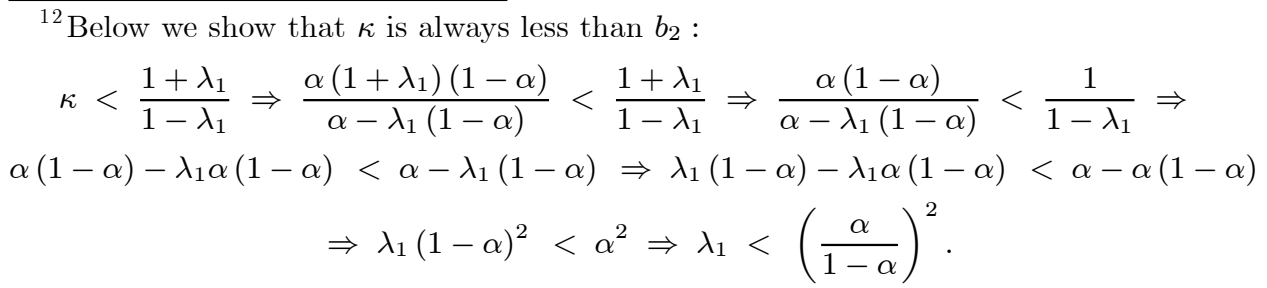

The latter inequality is valid since $\frac{1}{2}<\alpha<1$. Thus $\kappa$ is always smaller than $b_{2}$.

${ }^{13}$ Also, note that the effect of time on the unemployment responses is given by

$$
\frac{\partial R\left(u_{t}\right)}{\partial t}=-\frac{\lambda_{1}^{t}\left(1+\lambda_{1}\right)}{2\left(1-\lambda_{1}\right)}\left[\left(1-\lambda_{1}\right) \kappa-\lambda_{1}\right] \ln \lambda_{1}, t \geq 1 .
$$




\section{Appendix 3: OLS Estimates of the Unemployment, Price, and Wage Equations}

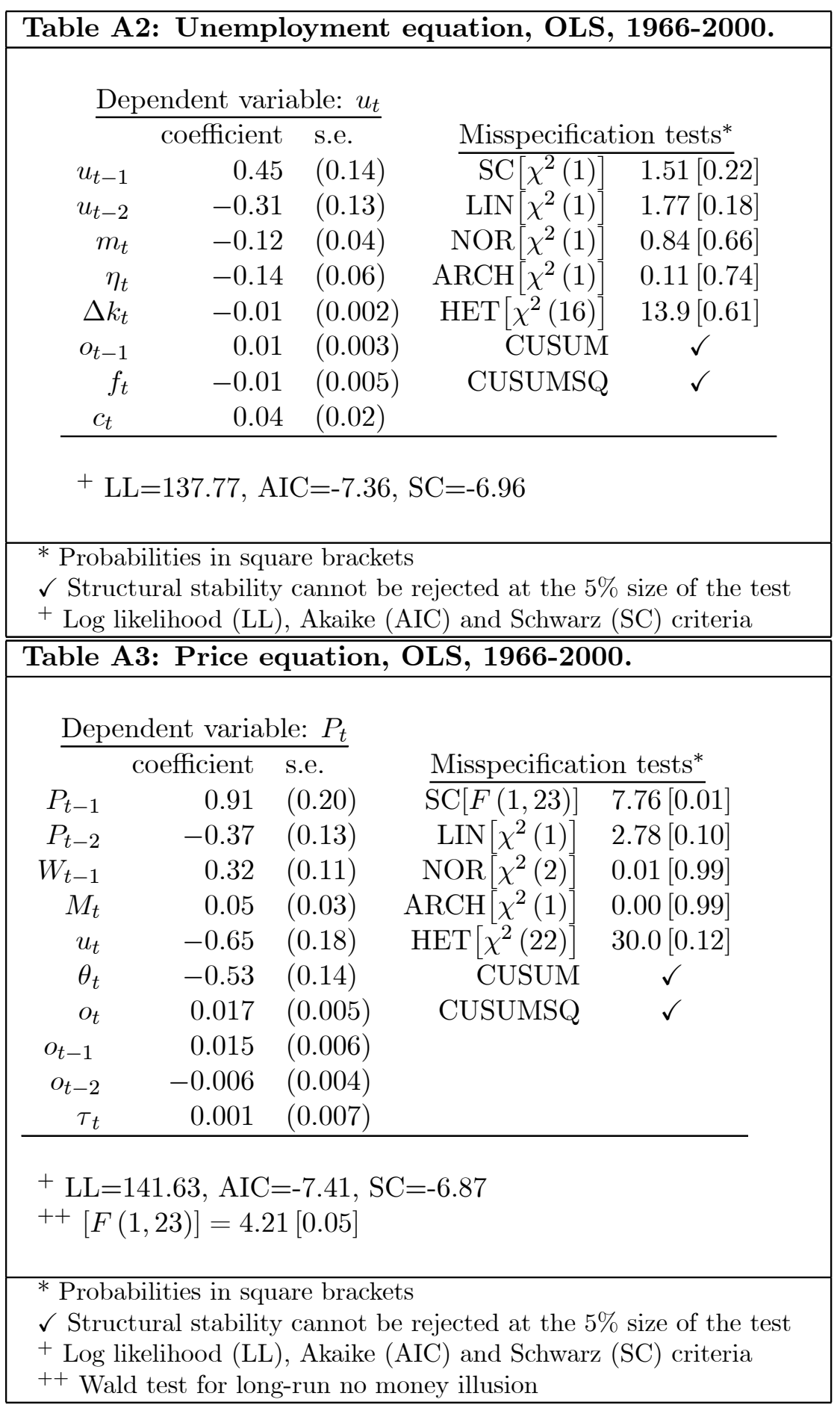




\begin{tabular}{|c|c|c|c|c|}
\hline \multicolumn{5}{|c|}{ Dependent variable: $W_{t}$} \\
\hline & coefficient & s. e. & \multicolumn{2}{|c|}{ Misspecification tests* } \\
\hline$W_{t-1}$ & 0.19 & $(0.11)$ & $\mathrm{SC}\left[\chi^{2}(1)\right]$ & $\overline{3.04[0.08]}$ \\
\hline$\Delta W_{t-2}$ & 0.47 & $(0.12)$ & $\operatorname{LIN}\left[\chi^{2}(1)\right]$ & $1.10[0.29]$ \\
\hline$P_{t}$ & 0.73 & $(0.12)$ & $\operatorname{NOR}\left[\chi^{2}(2)\right]$ & $1.76[0.42]$ \\
\hline$M_{t}$ & 0.08 & $(0.03)$ & $\operatorname{ARCH}\left[\chi^{2}(1)\right]$ & $0.06[0.80]$ \\
\hline$u_{t}$ & -0.41 & $(0.21)$ & $\operatorname{HET}\left[\chi^{2}(14)\right]$ & $15.1[0.37]$ \\
\hline$\theta_{t}$ & 0.35 & $(0.10)$ & CUSUM & $\checkmark$ \\
\hline$b_{t}$ & 0.05 & $(0.02)$ & CUSUMSQ & $\checkmark$ \\
\hline \multicolumn{5}{|c|}{$\begin{array}{l}{ }^{+} \mathrm{LL}=127.54, \mathrm{AIC}=-6.83, \mathrm{SC}=-6.48 \\
++[F(1,27)]=0.07[0.80]\end{array}$} \\
\hline \multicolumn{5}{|c|}{$\begin{array}{l}\text { * Probabilities in square brackets } \\
\checkmark \text { Structural stability cannot be rejected at the } 5 \% \text { size of the test } \\
+ \text { Log likelihood (LL), Akaike (AIC) and Schwarz (SC) criteria } \\
++ \text { Wald test for long-run no money illusion }\end{array}$} \\
\hline
\end{tabular}




\section{Appendix 4: Actual and Fitted Values of the Estimated System}
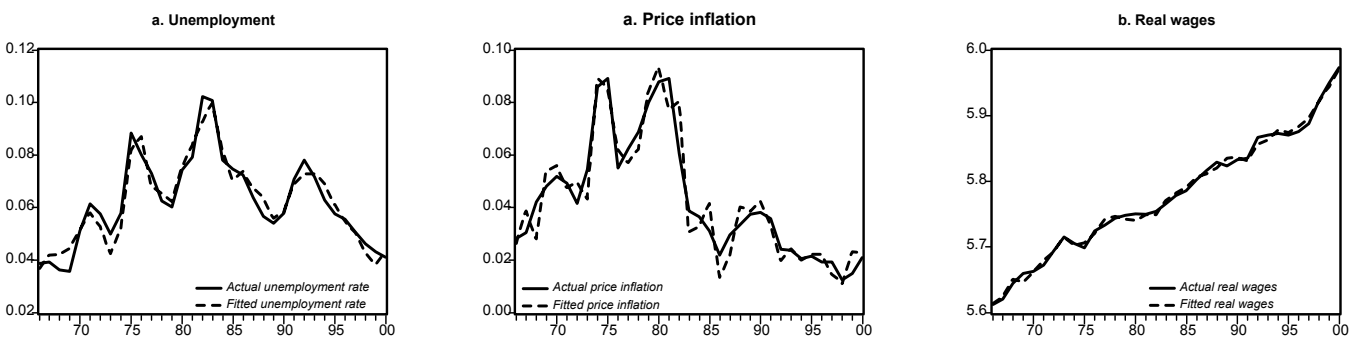

\section{Appendix 5: Further Evidence on Whether the Long-Run Phillips Curve is Vertical}

In the following table we present the percentage count of slopes within specific class intervals. For example, the probability that the long-run Phillips curve slope lies in the interval $(-6,-1.5)$ is $89 \%$.

\begin{tabular}{|rrrr|}
\hline Table A5: & \multicolumn{3}{l|}{ probability that the PC slope } \\
& is within a specific interval \\
\hline Slope interval & $(-\infty,-6)$ & $(-6,-1.5)$ & $(-1.5, \infty)$ \\
Probability & $10.4 \%$ & $89.0 \%$ & $0.6 \%$ \\
\hline
\end{tabular}

We also grouped the values of the generated series $S^{(i)}, i=1,2, \ldots, 1000$, into class intervals of 0.5 units. Using as a cut-off point a $10 \%$ count, there is no class interval below $[-4.5,-4.0)$ or above $[-2.5,-2.0)$ that contains at least $10 \%$ of the values of slope series $S$. These class intervals and their respective probabilities are given in the table below.

\begin{tabular}{|cccccc|}
\hline \multicolumn{5}{|c|}{ Table A6: } & \multicolumn{4}{c|}{ Monte Carlo simulations, 1000 replications } \\
class intervals with a count above 10\% \\
\hline Slope interval & {$[-4.5,-4.0)$} & {$[-4.0,-3.5)$} & {$[-3.5,-3.0)$} & {$[-3.0,-2.5)$} & {$[-2.5,-2.0)$} \\
Probability & $11.1 \%$ & $14.3 \%$ & $18.0 \%$ & $12.8 \%$ & $11.9 \%$ \\
\hline
\end{tabular}

